InLiSt No. 15

Interaction and Linguistic Structures

\title{
Pre- and post-positioning of wenn-clauses in spoken and written German*
}

\author{
Peter Auer
}

Freiburg

March 2000

\footnotetext{
* The corpus research on which this paper is based was supported in many and substantial ways by Benjamin Stoltenburg. Thanks to Jessica Wallace for correcting the worst blunders in my English, and to Susanne Günthner as well as to Elizabeth Couper-Kuhlen and Bernd Kortmann for their comments on a previous version.
} 
In recognition of the enthusiasm he has brought to all aspects of the study of spoken verbal interaction, we dedicate this series to Professor Dr. Aldo di Luzio, University of Konstanz.

Prof. Dr. Elizabeth Couper-Kuhlen PD Dr. Susanne Günthner

Universität Konstanz

FB Sprachwissenschaft

PB D 180

D-78457 Konstanz

http://ling.sprachwiss.uni-konstanz.de/pages/anglistik/
Prof. Dr. Margret Selting

Universität Potsdam

Institut für Germanistik

Postfach 601553

D-14415 Potsdam
Prof. Dr. Peter Auer

Albert-Ludwigs-Universität Freiburg

Deutsches Seminar I

Postfach

D-79085 Freiburg i. Br.

Additional copies may be ordered from:

Universität Konstanz, Sekretariat LS Angl. Sprachwissenschaft, InLiSt

PB D 180, D-78457 Konstanz, Tel.: +49/7531/88-2552, fax: +49/7531/88-4157

http://inlist.uni-konstanz.de 


\section{Introduction}

This paper is concerned with the distinction between pre- and postpositioned (initial and final) wenn-clauses in German, and with the distinction between written and spoken language. A simple cross-tabulation of the two features [spoken/written] and [pre-/ postpositioned] (section 3) shows that initial wenn-clauses are preferred in spoken German, but final wennclauses are preferred in written German. These findings are in need of an explanation, which will be given in sections 4 and 5 . Section 2 sketches the main characteristics of German wenn-clauses as compared to English conditional (if-) clauses.

The findings and discussions in this paper are corpus-based. They are partly quantitative, partly qualitative. With respect to both dimensions, the claim is that a full understanding of the syntax of (particularly) spoken language eludes the possibilities of a purely introspective methodology. Of course, no (quantitative or qualitative) corpus-based investigation can do without a strong reliance on the analyst's knowledge (,intuition') about the language being researched; in fact, finding valid generalizations always involves Gedankenexperimente playing with structural changes in and recontextualizations of the examples' found to be used by the informants. On the other hand, not even the empirical starting point of the present investigation (i.e., the (differing) preferences of spoken and written language for post- and prepositioning) is available to a purely introspective approach, since it is of a quantitative kind. In order to reach an explanation of these findings, this quantiative analysis has to be complemented by an in-depth analysis of individual cases of usage. Such an analysis will pay attention (a) to the in-time emergence of syntactic patterns, including the details of their delivery such as hesitations, reformulations, break-offs, etc., and (b) to the interactional aspects of this emergence, including hearer feedback (or lack of it) and sequential placement. In this respect, spoken language research can profit in important ways from conversation analysis.

\section{German wenn-clauses and English if-clauses: a brief syntactic and semantic overview}

This, of course, is not the place for a full contrastive analysis of the two constructions. In order to facilitate the reader's access to the examples to be discussed below, and in order to link up the present investigation with previous ones on if-clauses in spoken (and written) English, a short sketch of some important similarities and differences may however be in order here. 


\subsection{Syntax}

The syntax of English suggests a (misleading) parallel between pre- and postpositioned adverbial clauses (including conditionals), since they can usually be exchanged without structural changes in either the main or the dependent clause. German syntax, on the other hand, treats the two positions quite differently. While post-positioned adverbial clauses always occupy the so-called post-field (Nachfeld), which is not obligatory, and are thus tagged on to an already complete syntactic pattern, pre-positioned subordinated clauses may be (and in written, normative language usually are) more tightly integrated into the syntactic structure of the following main clause: they occupy the so-called front field (Vorfeld) of the sentence, i.e., the uniquely available and obligatory position before the finite verb. Moving adverbial clauses from one to the other position therefore involves structural changes in the main clause:

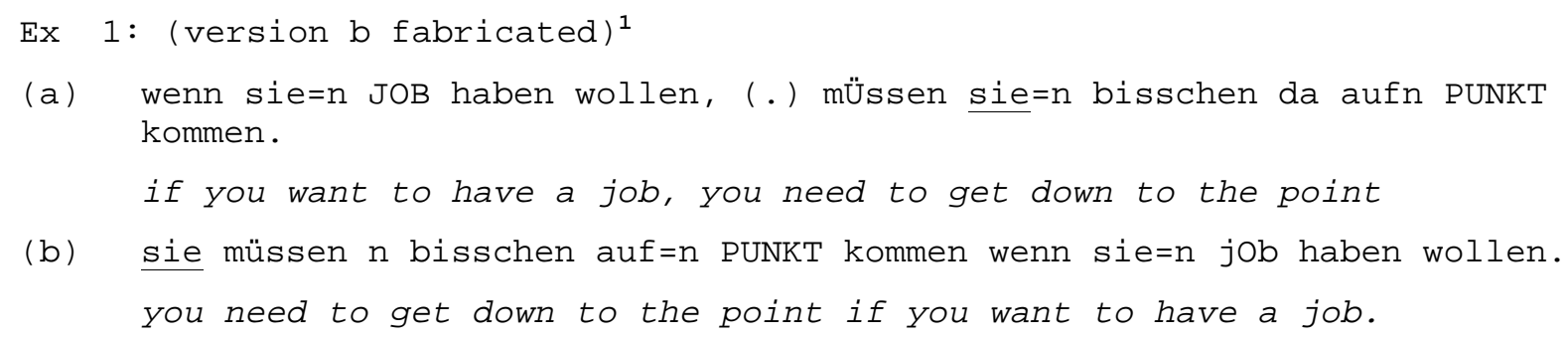

Positioning the wenn-clause in the post-field (=version b) instead of the front-field (=version a) implies that another constituent will fill this position (in the present case, it is the subject pronoun Sie). The dominant syntactic pattern in which pre-positioned adverbial clauses occur in written German may therefore be called „integrative“, while the English treatment is „nonintegrative" (cf. König \& van der Auwera 1988:103-9 for this terminology and some further remarks). In spoken German, however, the fully integrated placement of the pre-positioned adverbial clause in the front-field is only one possibility. Alternatively, pre-positioned wennclauses may be followed by a resumptive particle (a local-temporal adverbial such as dann or one of its regional equivalents, e.g. na, denn, no, etc.; cf. version (b) below); ${ }^{2}$ or they may even be used in a non-integrative way, rather like in English (version (c) below):

Ex 2: (versions b and c fabricated)

(a) wenn sie=n JOB haben wollen, (.) müssen sie=n bisschen da aufn PUNKT kommen.

if you want to have a job, you need to get down to the point

\footnotetext{
${ }^{1}$ Transcription of the spoken extracts follows GAT-conventions (cf. Selting et al. 1998); capital letters indicate stress positions. English translations are simplified, particularly with respect to prosody and hesitation phenomena. In case of conflict, less idiomatic versions have been chosen in order to give a better impression of German syntactic structure.

2 The wenn-clause itself should be seen as adjoined to the resumptive particle, i.e., as a co-constituent of the front-field; cf. Eisenberg ( $\left.{ }^{3} 1994: 364 f\right)$.
} 
(b) wenn sie=n JOB haben wollen, (.) dann mÜssen sie=n bisschen da aufn PUNKT kommen.

(same meaning)

(c) wenn sie=n WIRKlich $\mathrm{n}$ JOB hätten haben wollen; (.) sie hätten dann SCHON $\mathrm{n}=\mathrm{bisschen}$ aufn PUNKT kommen müssen.

if you had really wanted a job, (then) you would have needed to get down to the point.

For version (c), special conditions of use hold, and it may therefore be considered to be „marked“ (cf. König \& van der Auwera 1988, Köpcke \& Panther 1985, Günthner 1999, and below).

\subsection{Reduction}

As in English, pre-positioned wenn-clauses tend to be condensed into routine formulae; this reduction may eventually lead to a process of univerbation and to the emergence of a new modal adverbial (?) wenn dann, which is integrated into the sentence frame. Note the following degrees of reduction:

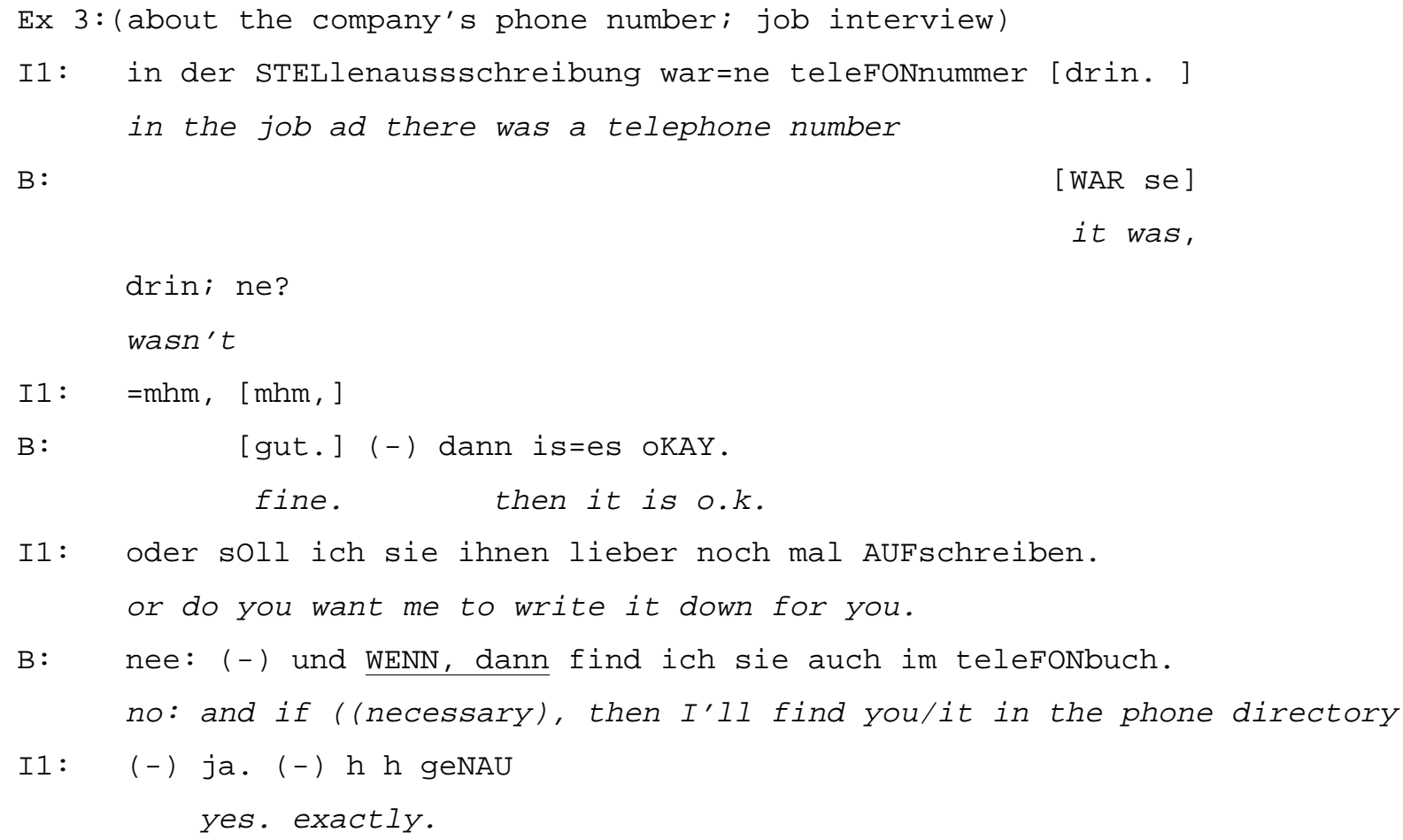

Here, the wenn-clause is reduced, but the reduction is a result of a context-specific ellipsis, and its meaning needs to be inferred from the context (if your phone number is not contained in the job ad'). It has retained its own intonation contour, separating it from the following resumptive dann. In the next example, however, the process of condensation has progressed further. This can happen if, semantically speaking, the conditional structure 
singles out a referential object (here: the ,Mercedes car' as the only one to which the predicate applies:

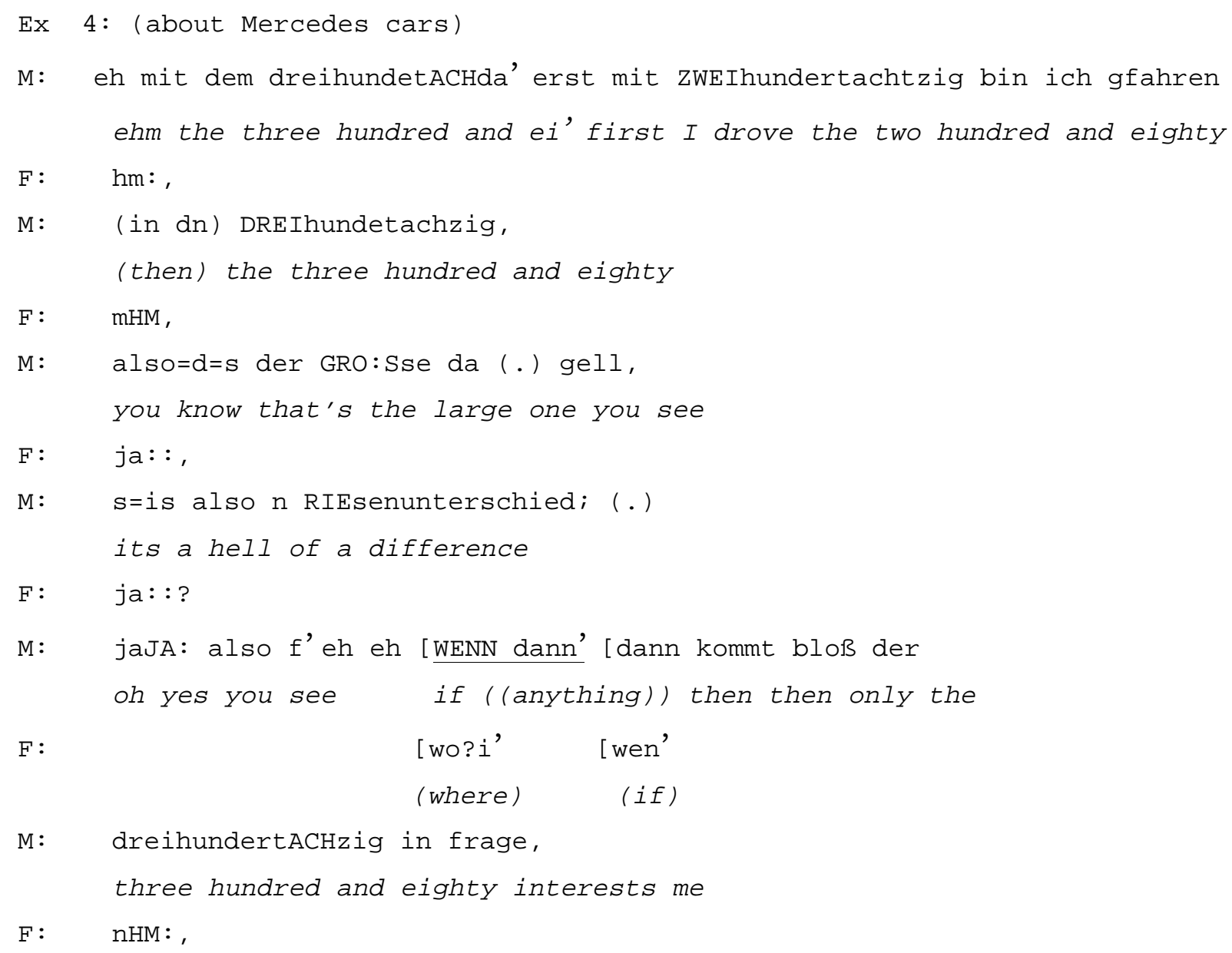

In this case, the reduced wenn-clause (i.e., , if anything only the three hundred and eighty ((model)) interests me' meaning, if anything interests me at all, it is the three hundred and eighty') needs no contextual inferencing; rather, it is directly tied to the syntactic structure it introduces. The routinization of the wenn-clause as wenn dann (or alternatively, wenn überhaupt (dann)) avoids a cumbersome process of ,raising: At the same time, the former conjunction wenn loses its prosodic independence and is integrated into the following intonation contour, to which it adds a (head-onset) accent in contour-initial position.

Finally, under the same conditions, but differently from English, a German wenn-clause may be reduced to a mere wenn which can appear in the middle field of the (former main) clause:

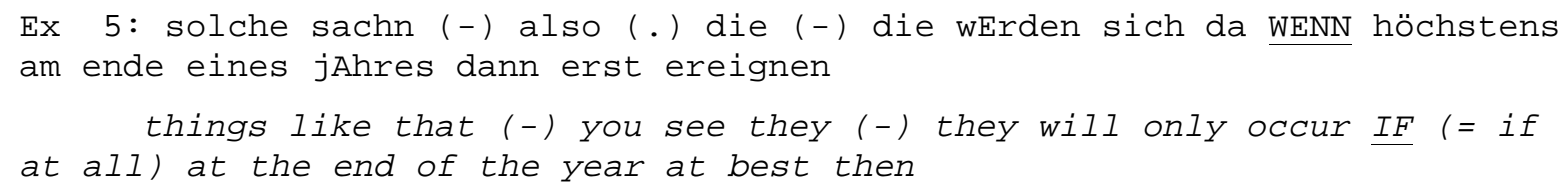


Here, wenn (optionally followed by überhaupt, at all') serves to modalize negatively the probability with which an event will occur. Its syntactic category as a conjunction is lost entirely.

\subsection{Semantics}

The semantics of German wenn-clauses ${ }^{3}$ is not strictly equivalent to English conditional ifclauses either. The cognate of English if, German ob (> Germanic *eba), has lost its original (OHG/MHG) function of introducing conditional clauses, although remnants of this usage may still be found in (etymologically) composite concessive conjunctions such as Modern German $o b+w o h l$ and $o b+g l e i c h$ and in concessive conditionals of the type ob $X$ oder nicht...(,whether $\mathrm{X}$ or not'). Filling the gap, the temporal conjunction wenn (or rather, its predecessors, MHG swenne/swanne), a cognate of English when, has taken over most of its functions. As a consequence, the semantics of wenn-introduced clauses oscillates between a temporal and conditional reading in the indicative mood. (For this reason, German wennclauses, other than English if-clauses, cannot be called CONDITIONAL clauses.) Only in combination with the subjunctive mood are wenn-clause unambiguously conditions. In the indicative mood, other conjunctions are available for a nonambiguous encoding of a conditional or a temporal relationship.

Disambiguation of wenn is possible on the basis of contextual information (i.e., the semantics of the remainder of the clause and/or its conversational context) in some, but certainly not all cases. Even in the following examples (which are among the clearest in my data) the paraphrases are not entirely beyond dispute. However, they do represent the prevalent semantic readings of wenn-clauses (in the indicative mood):

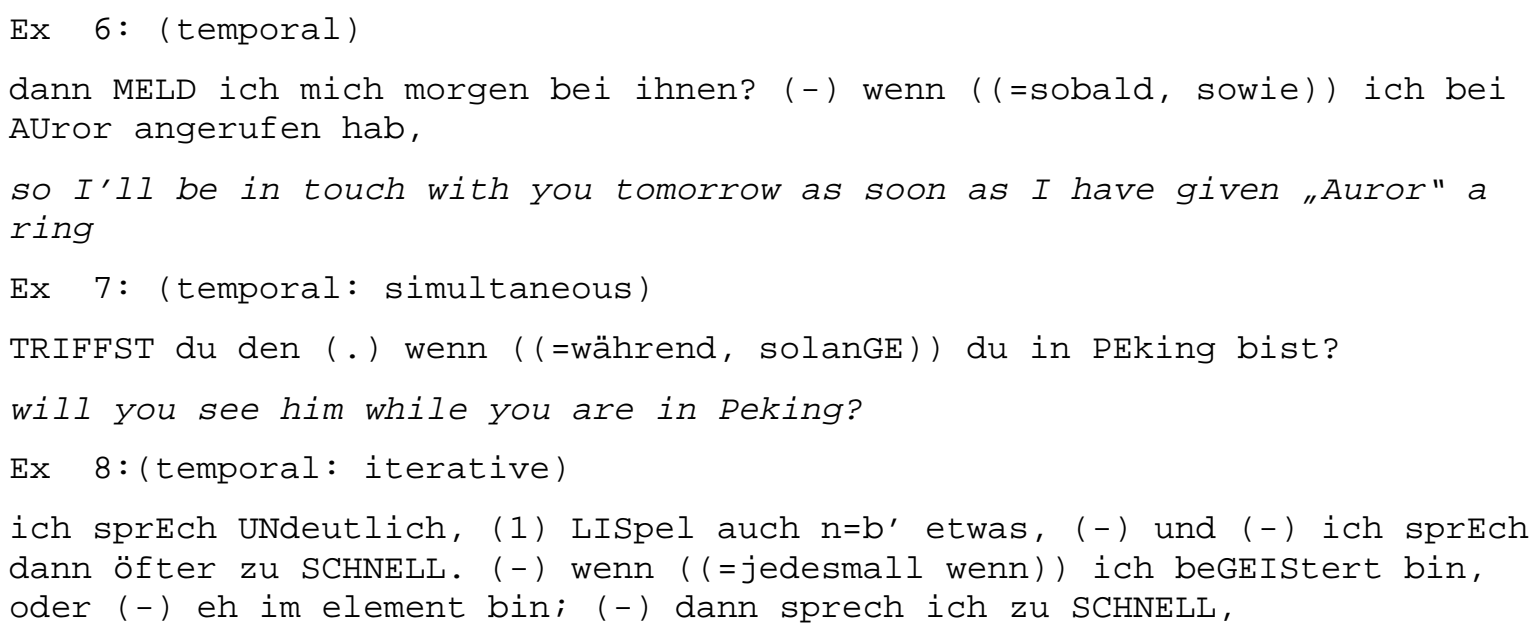

${ }^{3}$ For a detailed discussion, see Metschkowa-Atanassowa 1983 and Zifonun et al. 1997:2280-2293. 
I speak inarticulately, I also lisp a little, and then I often talk too

fast. whenever I am enthusiastic about something, or ehm get carried away;

(-) then I talk too fast,

Ex 9: (conditional: hypothetical)

er will sie jetzt wieder HEIraten, und die haben so ne FRIST ehm in den islamischen ländern dass innerhalb von nem halben JAHR oder so, muss die frau dann wieder zum MANN zurück wenn ((=für den Fall dass, falls)) er sie DOCH wieder will h.

he now wants to marry her again and they have kind of a deadline ehm in the Islamic countries that within half a year or so the wife has to return to her husband in case he wants her back again

Ex 10: (conditional: factual)

( (radio phone-in, psychotherapeutic consulting; the caller has complained about having no-one to turn to with his marriage problems; the therapist recapitulates and formulates her advice))

denn LETZTlich.h wenn ( (=da)) sie in ihrer verwAndtschaft niemand HAbn mit dems REden können, .h äh is=danns BESte, (-) sie würden zu am Eheberater gehn?

for in the end, since you have nobody among your relatives who you could talk to, ehm it's best then to turn to a marriage counsellor

Clearly, the temporal readings of wenn are not covered by English if, but by when instead.

Some verbal and prosodic features of indicative wenn-clauses may facilitate or even enforce one or the other reading: (a) the temporal, non-iterative reading is not available in sentences referring to past events; here, the temporal conjunction als takes over (while English allows when); (b) focussing adverbials such as stressed nur (,only') in the main clause strongly suggest a conditional reading of the (following) wenn-clause; (c) the particle schon (no English equivalent) in the wenn-clause suggests a factual-conditional reading; (d) immer wenn (,always when') instead of a simple wenn as a conjunction enforces a habitualtemporal/ contingent reading; (e) selbst wenn (,even if') and wenn ... überhaupt (,if ... at all') instead of a simple wenn enforce a conditional reading; (f) subjunctive (Konjunktiv II) in the wenn-clause enforces a hypothetical-conditional reading; (g) stressed wenn-conjunctions suggest a conditional instead of a temporal reading; for this last cue, consider:

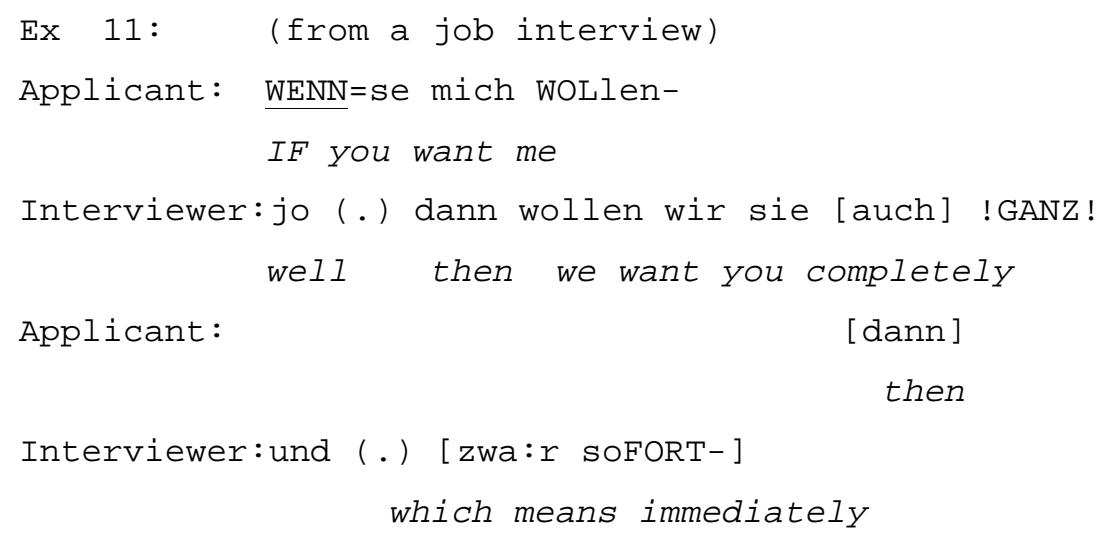


Here a wenn-dann construction is co-construed by the applicant and the interviewer in a job interview; the applicant starts out with a wenn-clause which could be read temporally (,as soon as you want me') or conditionally (,in case you want me'), as long as prosody is not taken into account. However, the following main clause provided by the interviewer unambiguously selects the first reading. Arguably, the basis for this selection is the stressed conjunction (here constituting the head onset of the intonation contour).

Two special uses of wenn-clauses need to be mentioned here. The first is the expression of concessivity through the combination of wenn and auch (wenn + auch or auch + wenn), roughly similar to Engl. even if/even though: ${ }^{4}$

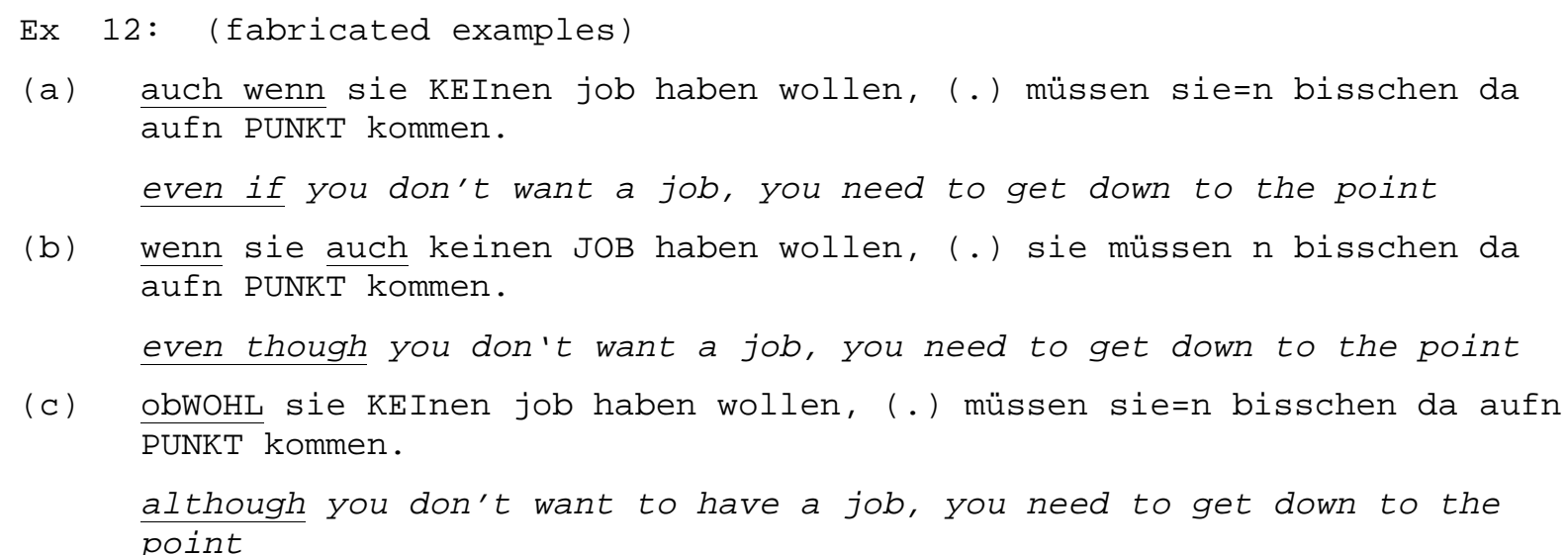

The auch wenn-construction (version (a)) differs from obwohl-concessives (Engl. although, version (c)) in that the truth of the proposition it expresses can but need not be taken for granted („neutral epistemic stance“; cf. Fillmore 1990, Couper-Kuhlen, 1999): whereas the proposition ,you don't want a job' is not asserted in version (a)/auch wenn, it is in version (c)/obwohl. Auch-wenn -clauses therefore differ from if-conditionals and resemble true (obwohl-)concessives in that the presupposed generic statement is negative (for the above example: ,someone who does not want a job does not have to get down to the point'). At the same time, they differ from true concessives and are similar to true conditionals in that the truth of the antecedent may but need not be asserted. Note that, differently from auch wenn, pre-positioned wenn auch-clauses (version (b)) often co-occur with non-integrative word order in the consequent.

Finally, it should be noted that German wenn-clauses are sometimes obligatory constituents of the verb. ${ }^{5}$ (English often uses non-finite forms such as participle or infinitive clauses for this purpose, although if-clauses are also possible.)

\footnotetext{
${ }^{4}$ For an analysis of these „concessive conditionals“, cf. König 1985.
} 


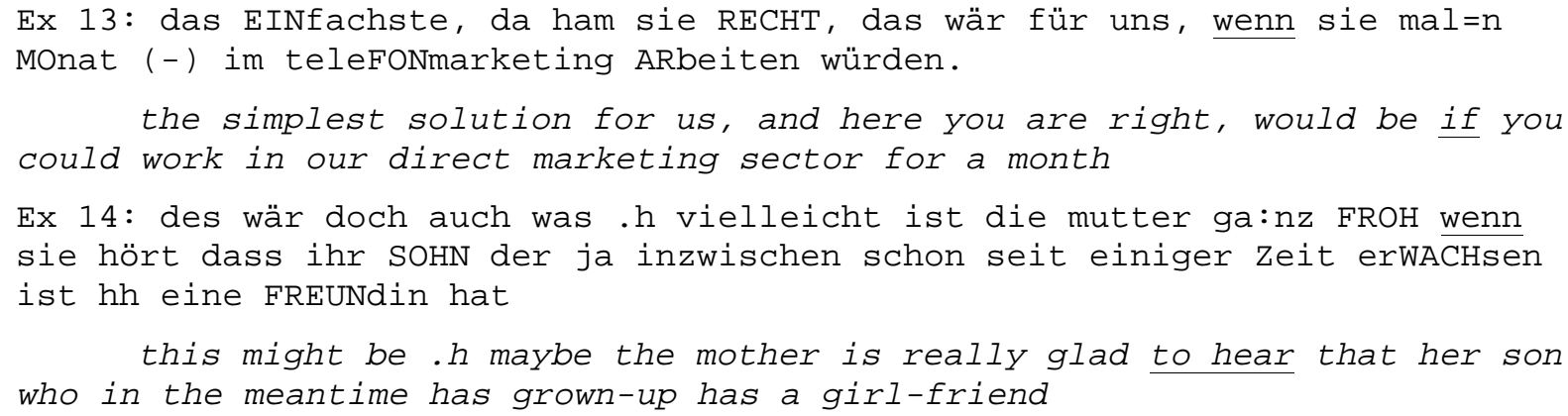

Syntactically speaking, wenn-clauses of this kind can be replaced by dass-(complement) clauses (das Einfachste wäre, dass sie mal im Telefonmarketing arbeiten/ vielleicht ist die Mutter ganz froh, dass (sie hört, dass) ihr Sohn eine Freundin hat). Semantically speaking, various differences result from the choice between dass- and wenn-complements; most of them pertain to the presumed status of the information in the complement clause (cf. Eisenberg ${ }^{3} 1994: 365 f$. for some further discussion).

\section{German wenn-clauses from a quantitative perspective}

The observations in this section are based on a collection of 500 wenn-clauses taken from a corpus of spontaneous, direct conversations. ${ }^{6}$ All instances of wenn were considered for analysis, apart from obvious syntactic break-offs in the wenn-clause, some nonreconstructable utterances, and the comparative uses of als/wie wenn (see note 5). In Fig. 1, the total of $n=500$ tokens is broken down according to the position of the adverbial clause relative to the main clause: pre-positioning, post-positioning, parenthetical positioning within the clause ${ }^{7}$, independent use of the wenn-clause as a turn-constructional unit of its own, and a residual category of ambiguous cases (e.g. apo-koinuconstructions, see below). There can be no doubt that the front position is preferred in spoken German.

\footnotetext{
${ }^{5}$ Among these wenn-clauses in the role of obligatory constituents, we may also count comparisons using wie wenn and als wenn, as in: du kommsch dir vielleicht vor wie wenn dir deine wErte verLORN gangn sin. (,maybe it seems to you as if your values had been lost'). This usage of wenn will not be taken into account in the following discussion, nor has it been included in the quantitative analysis.

A note in passing: some grammarians believe that wenn-clauses in complement function are obligatorily marked by a resumptive es (e.g. Eisenberg $\left.{ }^{3} 1994: 365\right)$; this is not supported by my data, however.

${ }^{6}$ Some $40 \%$ of the corpus are job interviews, mainly collected among north and east German speakers, some $30 \%$ are therapeutic conversations, both in face-to-face and in radio phone-in contexts, and the remaining 30\% represent private everyday conversations, partly on the telephone. In the latter two types of data, southern German speakers prevail.

${ }^{7}$ Embeddings of wenn-clauses into complex hypotactic constructions were not counted as parenthetical.
} 


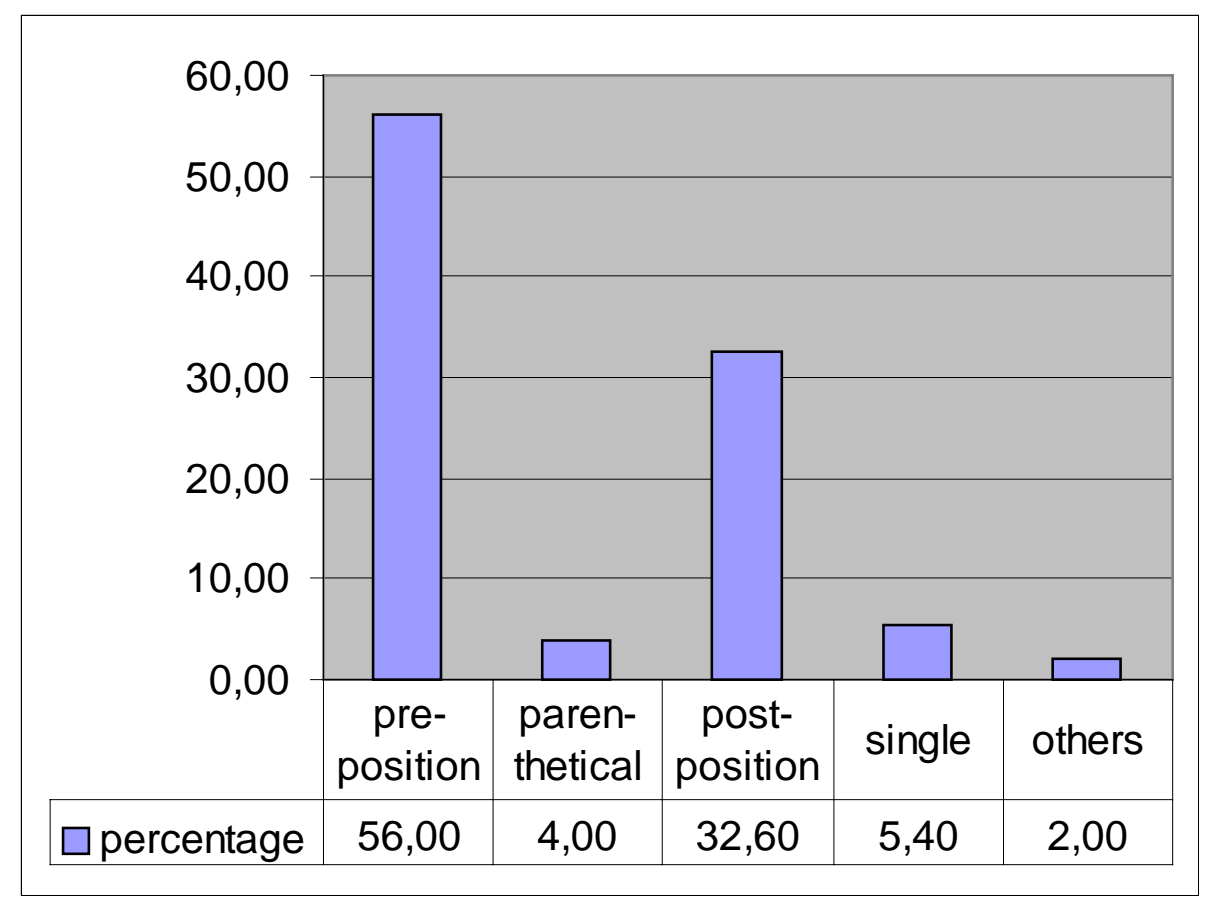

Fig. 1: Position of German wenn-clauses relative to the main clause; $n=500$.

The results agree with Ford \& Thompson's findings on if-clauses in English conversations, according to which initials outnumber finals by a ratio of $4: 1 \quad(n=316$, initial=81\%, final=19\%; Ford \& Thompson 1986:362), with Ford's findings based on a smaller collection ( $n=52,50 \%$ of which where preposed, 35\% postpositioned, and 15\% single; cf. Ford 1993:24), and with more general claims about a universal preference for pre-positioning of antecedents in conditional constructions (Greenberg 1963). Note, however, that the preference found in the English data for pre-positioning of conditional clauses does not extend to temporal (e.g., when-) clauses; rather, Ford (1993:24) found these to follow their main clauses by a ratio of 2:1. Given the ambiguity of German wenn-clauses (in the indicative mood) between a conditional and a temporal reading, it may be asked if the preference for initial placement of wenn-clauses holds for both. In the Fig. 2, those instances of wenn-clauses have been singled out $(n=203)$ which have either a clear temporal or a clear conditional reading (based on the substitution tests and criteria discussed in section 2.3). ${ }^{8}$

\footnotetext{
${ }^{8}$ The count excludes, in addition to all polyvalent cases, all factual conditionals (i.e. those expressing a positive epistemic stance), which are always non-temporal, and all concessives, as well as wennclauses used as complements, but includes counterfactual conditionals and reduced wenn-dann routines.
} 


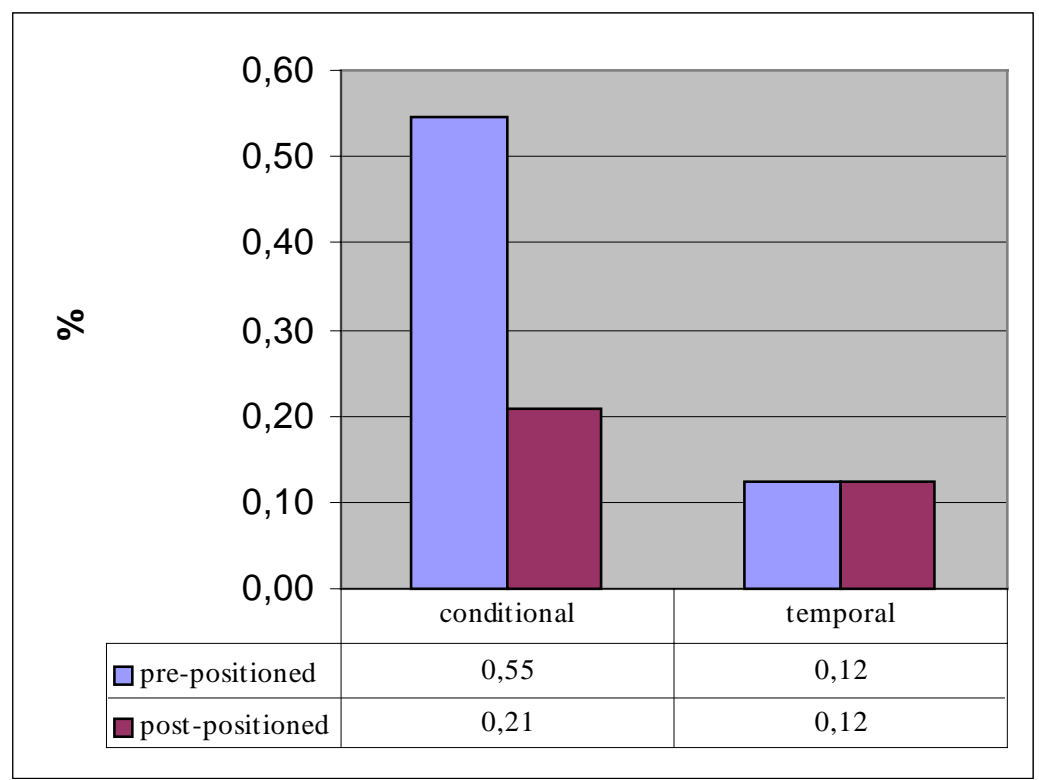

Fig. 2: Pre- and postpositioned wenn-clauses with temporal or conditional meaning $(n=203)$

Of the $n=203$ disambiguated wenn-clauses, $24 \%$ have temporal, the remainder conditional meaning. Exactly half of the wenn-clauses with temporal meaning are prepositioned and postpositioned respectively. There is, then, a clear difference between conditional and temporal uses: only for the former does the preference for pre-positioning hold. Since the majority of German wenn-clauses are semantically ambiguous between a temporal and a conditional reading, this finding also suggests that, taken as a whole, they behave syntactically like (English) conditional rather than temporal clauses.

Fig. 3 shows the percentage of integrative, resumptive and non-integrative constructions among the pre-positioned wenn-clauses in the sample $(n=280)$. 


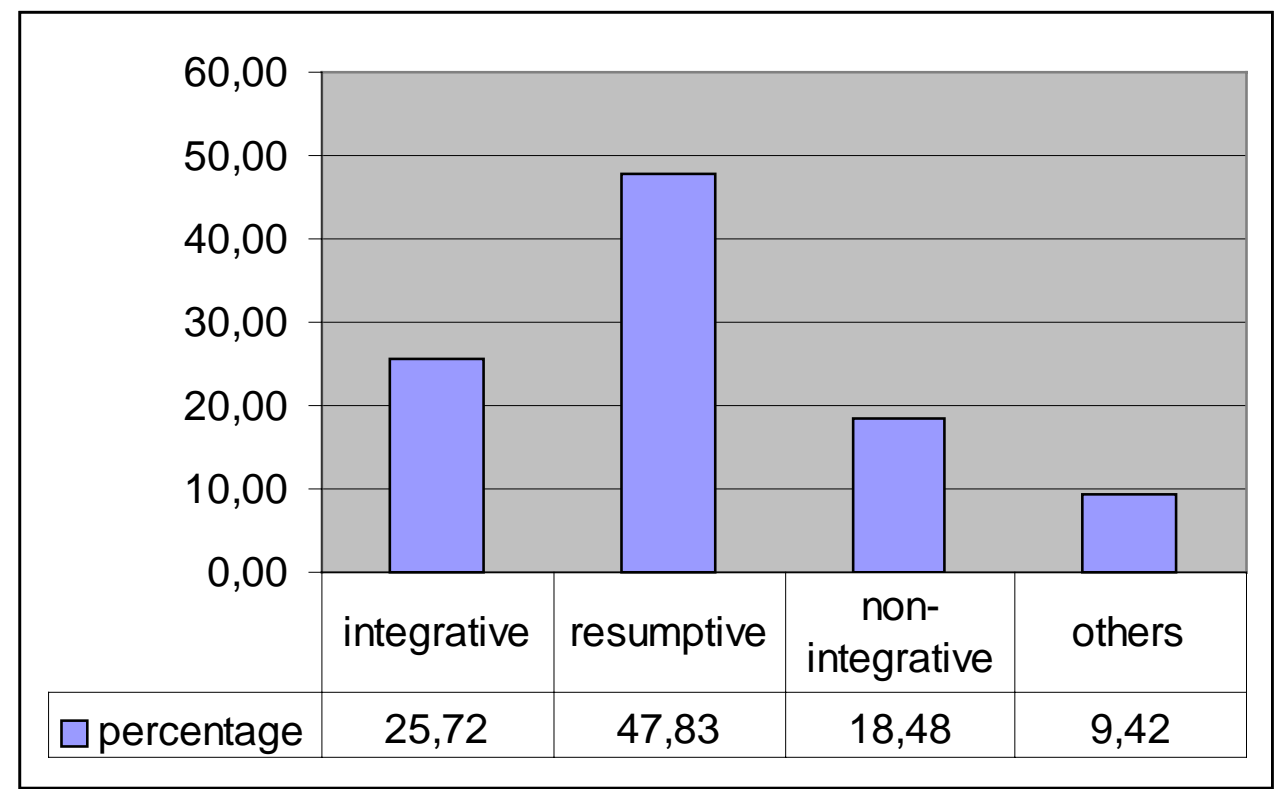

Fig. 3: integration (\%) of pre-positioned wenn-clauses into the subsequent main clause $(n=280)$

The relatively large residual category („others“) covers wenn-clauses plus subsequent main clauses within larger hypotactical constructions (see below example (26)-(28)). Again, the results are very clear: resumptive constructions are preferred to fully integrated and totally non-integrated constructions. The canonical, integrative construction of standard written German only plays a secondary role in spoken German.

Some comments on non-integrative wenn-clauses in German are necessary at this point. Pre-positioned wenn-clauses occurring in the pre-front field of a sentence are basically of two types (cf. Auer 1996). We find instances which cannot be positioned in the front field (i.e., integrated into the main clause); in other words, the only available pattern for them is nonintegrative syntax. This is sometimes for syntactic reasons; in particular, yes/no-questions and imperatives, which are verb-initial syntagms in German, do not have a front field, and in $w$-questions, the $w$-question word is usually said to occupy the front-field. ${ }^{9}$ In these contexts, adverbial clauses either need to be post-positioned (despite the general preference for prepositioning), or to be non-integrative. Of the 45 questions/imperatives in the sample, 16 have pre-positioned wenn-clauses, i.e., non-integrative word order (cf. Ex 15), while 29 have postpositioning; this means that the normal preference is reversed in this syntactic environment.

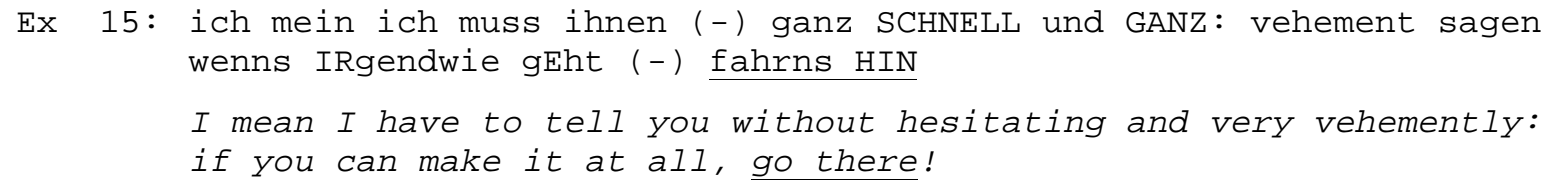

\footnotetext{
9 * Warum [wenn Du Kirschen magst] pflückst Du Dir keine vom Baum? ,Why [if you like cherries] don't you pick any from the tree?" therefore has to be understood as parenthetical. Resumption by dann is also excluded here, i.e., non-integration is the only option.
} 
However, there are also semantic reasons why certain wenn-clauses have to occur in the pre-front instead of the front field. This is the case for „speech-act related“10 wenn-clauses which do not conjoin two propositions on the content level; often, they are used in order to mitigate subsequent face-threatening acts (such as, in the following example, an interruption). The apodosis is asserted independently of the protasis, and this semantic independence corresponds with obligatory syntactic non-integration:

Ex 16: ((job interview))

wenn ich (-) grad WEIter ausführen darf; (0.5) Sie wissen ja in de: in der

AUtoinduschdrie.h herrschen SEHR große k' konkurRENZ, markt

if I may continue elaborating on that; (0.5) you know that in the car

industry there is a lot of competition ((etc.))

In such cases, the marked position of the wenn-clause in the pre-front field helps to contextualize a marked (non-referential) semantic interpretation.

But there are also contexts in which non-integrative syntax is frequent although not obligatory. For instance, there is a tendency for non-integrative clause-combining to occur in concessive wenn nicht-constructions:
Ex 17: wenn auch die theoRIE; (-) eh (-) so IRgendwo mal gehÖrt wurde im KOPF? (-) eh das UMsetzen das ist ja das entSCHEIdende, even though the theory (-) ehm (-) may have been heard somewhere in one's head (-) the decisive thing is putting it into practice

Another frequent function of non-integrated wenn-clauses is topicalization; in this case, the wenn-clause is typically followed by an anaphoric pronoun back-referencing the proposition expressed in the wenn-clause as a whole, or an element contained in it. In the following example, the wenn-clause introduces a new discourse referent or topic; it is in many ways equivalent to other topicalization constructions (such as a cleft construction: was Ihre Fragen angeht, die können Sie jetzt stellen), with the additional implication that the speaker is not certain about the relevance of the new discourse referent for the co-participant.

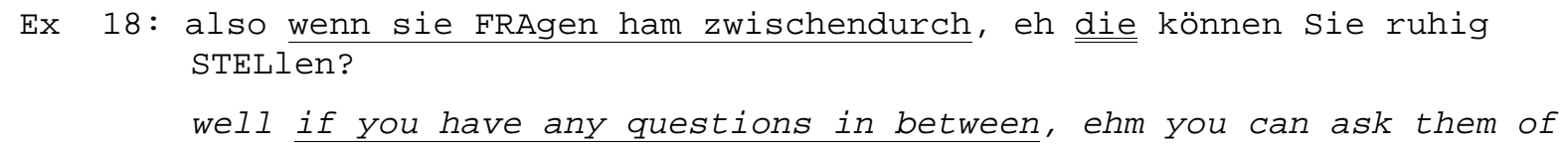

\footnotetext{
${ }^{10}$ The term is used in a broader sense here than in Sweetser 1990. Details on this construction may be found in Günthner, 1999. Note that Sweetser's „epistemic conditionals“, although not „,content conditionals", do not allow pre-front field placement in German ( ${ }^{*}$ Wenn er sich jeden Tag volllaufen lässt, sie hat ihn verlassen. ,If he gets drunk everyday, she has left him.').
} 
A similar topicalization (not of a single referent, but of a whole proposition) is involved in the following example:

Ex 19: un wenn ich mein Eltern anrufn würde, =ds würde AUCH nix bringn. and if I called my parents, that wouldn't be any use either.

Here, the wenn-clause could even be entirely replaced by an infinitival construction (meine Eltern anzurufen), since potentiality is already expressed by the conditional verb form würde...bringen and redundantly coded by wenn.

Finally, non-integrated wenn-clauses often express emphasis and lend an emotional meaning to the utterance: ${ }^{11}$

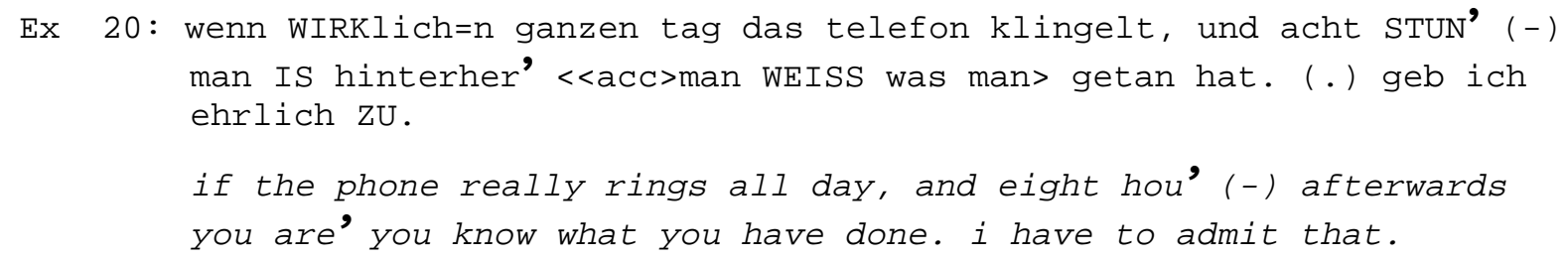

In (20), the speaker describes her working-day in a call-centre and wants to emphasizethat dealing with callers is a tiring job; one of the strategies used to convey this meaning is the non-integration of the protasis into the apodosis. ${ }^{12}$

\footnotetext{
${ }^{11}$ Cf. König \& van der Auwera 1988: 128 (,,assertive emphasis on a consequent of a concessive allows non-integration“), Köpcke \& Panther 1989: 700 (,high degree of ego involvement") and Günthner 1999 for details.

${ }^{12}$ In this context, König \& van der Auwera's claim should be mentioned that sentential conjuncts with und ,and', of which only the first has subordinated (verb-final) syntax but the second one is construed as a main clause, should occur with non-integrative word order in the superordinate (matrix) clause (1988). In my corpus, there is only one such example:
}

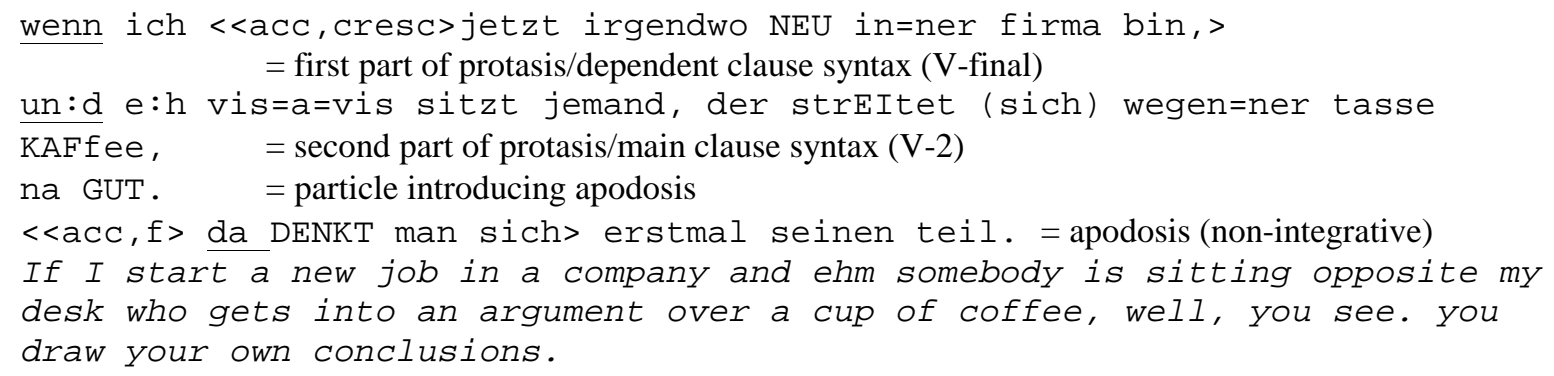

But the same type of anacoluthon is also regularly found in integrative wenn-constructions; e.g.:

wenn natürlich (.) mein chef SAgen würde oKEE, (.) .h <<acc>wir verLëNgern den vertrag> noch, $=$ first part of protasis/dependent clause syntax ( $\mathrm{V}$-final) .h und ich HAbe noch nichts, = second part of protasis/main clause syntax (V2) bin ich $\mathrm{AUCH}$ dran intressiert. ne, = apodosis (integrative) of course, if my boss said o.k., we'll give you a prolongation of your contract, and I haven't found anything else, I'm also interested in that, you see. 


\section{Some reasons for pre- and post-positioning}

What are the advantages of pre-positioning wenn-clauses? This question seems less difficult to answer than the opposite one of why a certain number of these clauses - roughly a third in our data - are post-positioned. We will deal with each question in turn.

\subsection{The advantages of pre-positioning}

To start with, it should be noted that the preference for pre-positioned wenn-clauses is not just a quantitative finding but is reflected in speakers' changes in the design of an emerging syntactic pattern ,in mid-stream: Particularly striking are cases such as Ex. (8), repeated here for convenience as Ex. (21), in which a post-positioned wenn-clause is retrospectively turned into a pre-positioned one via what might be called an apo-koinu construction:

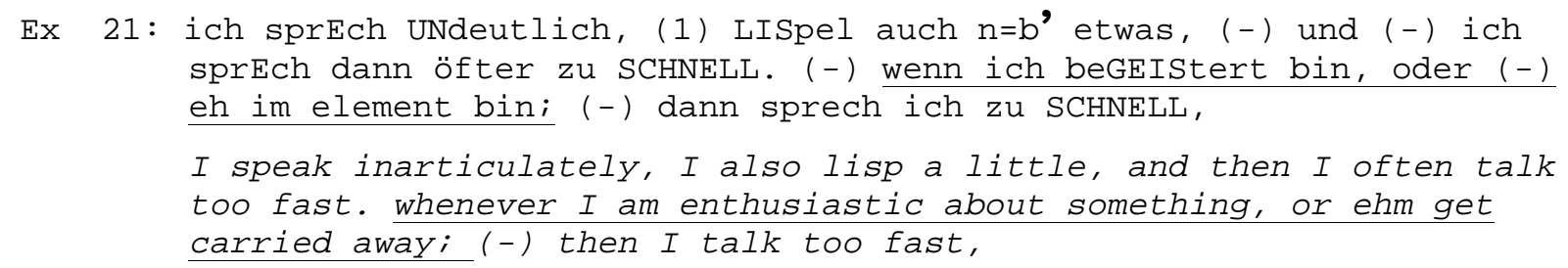

The koinon here, of course, is wenn ich beGEIStert bin, oder (-) eh im element bin. It seems that the speaker, having completed the three-part list of his verbal handicaps, wants to qualify the last item retrospectively. He could have done this by simply adding the wennclause in the post-field but recycles this last component instead, with the wenn-clause inserted before it. The wenn-clause here is both final and initial. Instances in which a clause is broken off and a wenn-clause is inserted before it is re-started (as in (22)) are also evidence for the interactional relevance of pre- vs. Post-positioning.

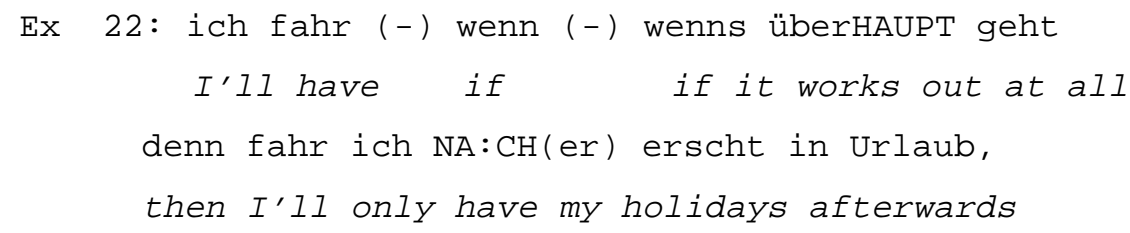

So why this additional effort? There seems to be some kind of cognitive ,naturalness' in the way in which conditionals create the ground - or, in more recent but equally metaphorical parlance, set up a „mental space“ (Fauconnier 1985) - in which some hypothetical or factual proposition is located. ${ }^{13}$ For cognitive reasons, it is the grounding which (iconically) precedes the focal proposition, and not the other way round. Ford, for instance, suggests that „the

${ }^{13}$ Cf., among others, Ford \& Thompson 1986: 370; Ford 1993; Dancygier \& Sweetser 1996. 
prevalence of initially placed if-clauses may reflect the general tendency to signal $((\ldots))$ that the interpretation of the coming clause will be, in some general way, limited by the contents of the if-clause" (1993:15). Further evidence for the ,naturalness" of this position can be derived from the affinity of conditional clauses and topic-introducing devices (topics precede comments), for which some evidence has been given in the preceding section (see Haiman 1978, Ford \& Thompson 1986 for an in-depth treatment of this line of argumentation), and from the affinity of conditional and causal clauses (where causes iconically precede their effects). The advantages of this discourse function seem to outweigh the cognitive costs linked to the deployment of a syntactic pattern which projects considerably into time.

It may not have been sufficiently taken into account in previous research on clause positioning, however, that this projection in time has an interactional side as well: ${ }^{14}$ speakers who open up far-reaching syntactic gestalts claim the turn for at least the time which is necessary to bring them to a well-formed conclusion. In other words, producing a wennclause gives the speaker the right and obligation to go on talking; it functions as a turnholding device until the formulation of the consequent is completed. There are numerous cases in the data in which highly complex turns emerge in this way, since the speaker uses the space between a gestalt-opening wenn-clause and a terminating main clause for detailing the „mental space“ opened up by the first component. Two elaborate examples (as they seem to be typical for institutional talk) are (23) and (24):

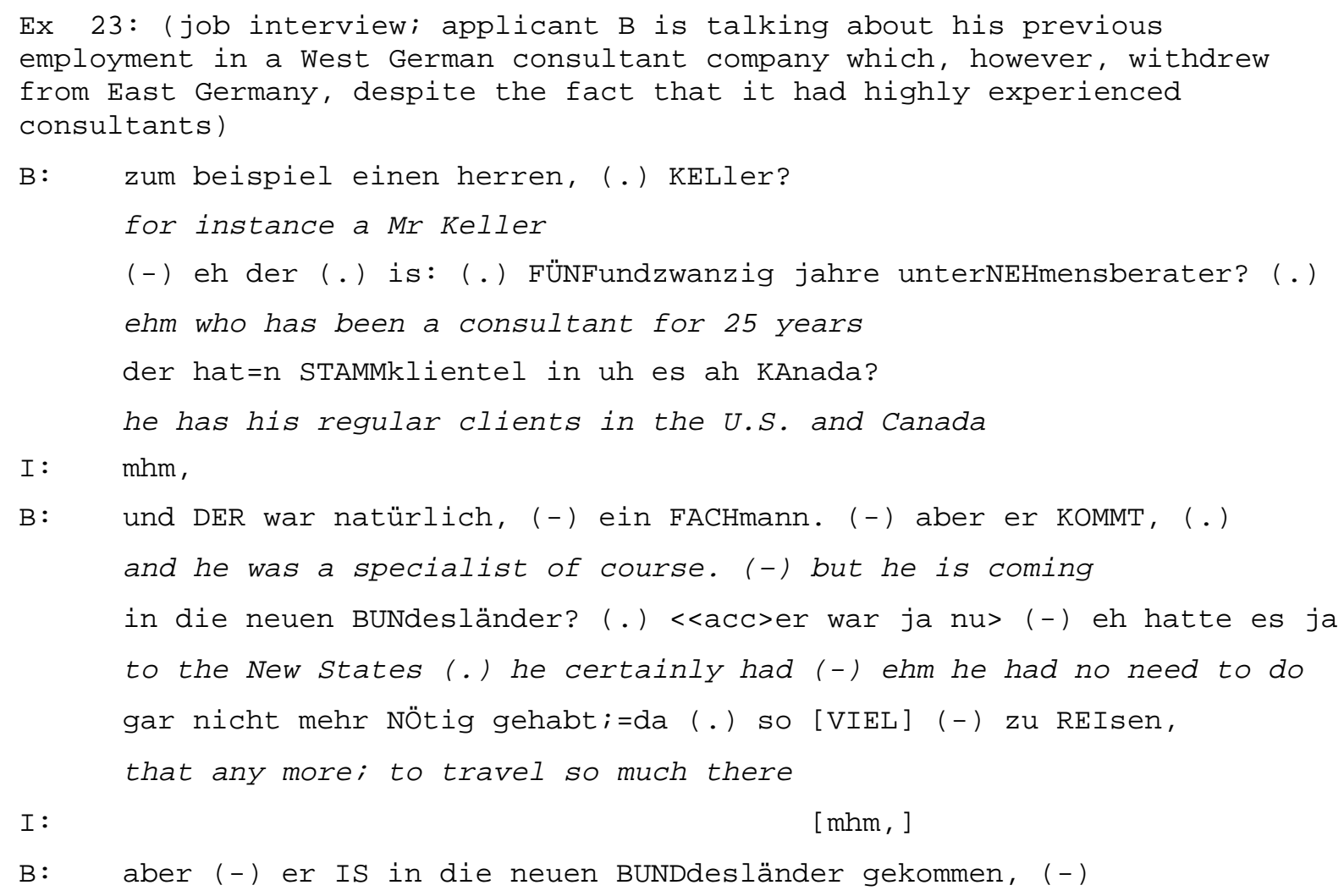

${ }^{14}$ But see Ford 1993:56. 


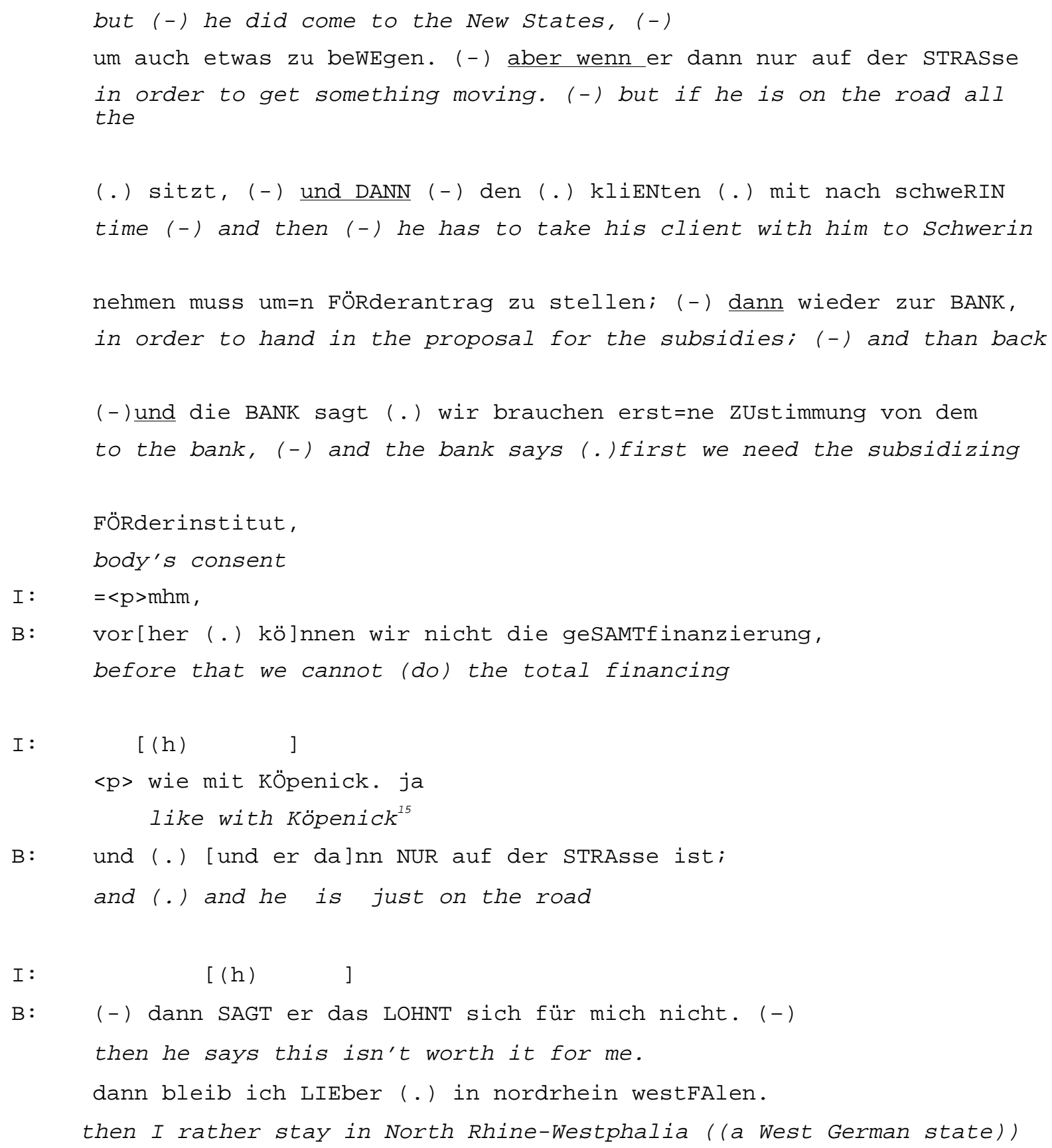

This passage is embedded into a larger report the applicant gives of his participation in a West German consultant agency in the New States, which however closed down its East German office, making him redundant. The interviewer does not seem to know the company and questions its importance on the market. The applicant counters by stating that although small, the company had very professional consultants. At the same time, he has to deal with the interviewer's innuendo that the company withdrew from the East German market because it was not working successfully. In this context, the case of "Mr. Keller" is mentioned, an experienced consultant who was disappointed by the kafkaesque way in

\footnotetext{
${ }^{15}$ Speaker I is most likely alluding to Zuckmayer's play (and a famous German movie) Der Hauptmann von Köpenick, in which the Prussian state and army authorities are caricatured.
} 
which state and bank authorities made it hard for new enterprises to get subsidies, and returned to the Old States.

After he has been portrayed as a successful consultant who came to East Germany mainly for idealistic reasons, „Mr. Keller's“ dissatisfaction with the situation is described in a complex turn construction which starts out with a wenn-clause (wenn er nun auf der Straße sitzt...). In the given context, the interpretation is not hypothetical but refers to a (factual) state of affairs (,since he was always on the road...'), which is established as the ground from which some conclusion can be drawn. Before this conclusion is reached, however, the speaker elaborates at considerable length on the unfortunate situation in which "Mr. Keller" and his clients found themselves; in four clauses each introduced by (und) dann, the various fruitless journeys between the financing bank and the state authorities in Schwerin are described. Towards the end of this elaboration (securely produced by the speaker within the realm of his own turn, since a syntactic projection - that of the when-clause - still remains to be taken care of), the interviewer produces some recipiency tokens which, although not claiming the turn (cf. their reduced loudness, indicating non-competitiveness), nevertheless acknowledge the speaker's point: two laughter particles and one comment (wie mit Köpenick) display understanding. Only after this feedback does the speaker close the syntactic gestalt with two resumptive dann-clauses. Their content is highly predictable, given the fact that it has been mentioned before that the company closed down its East German branch. It seems, then, that what the speaker wanted to convey by this complex turn is not so much this consequent but rather the details of the situation which led to it. The relevant information of this complex construction is what is produced BETWEEN the initial wenn-clause and the final dann-clauses. The speaker employs the projecting force of the first in order to claim conversational space for himself, and makes use of this space as long as he needs it to ,convince the recipient of his point (as evidenced by the recipient's responses). The ,orderly' conclusion of the turn is produced as soon as this purpose is reached.

The following extract similarly shows how pre-positioned wenn-clauses can be used to claim conversational space:

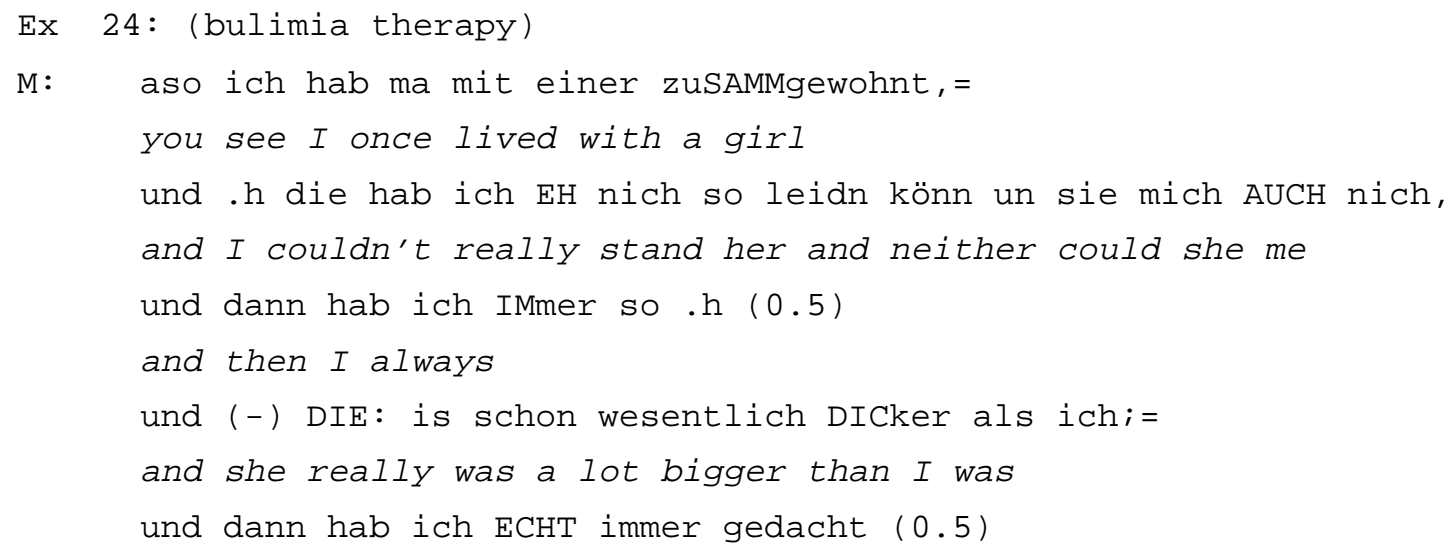




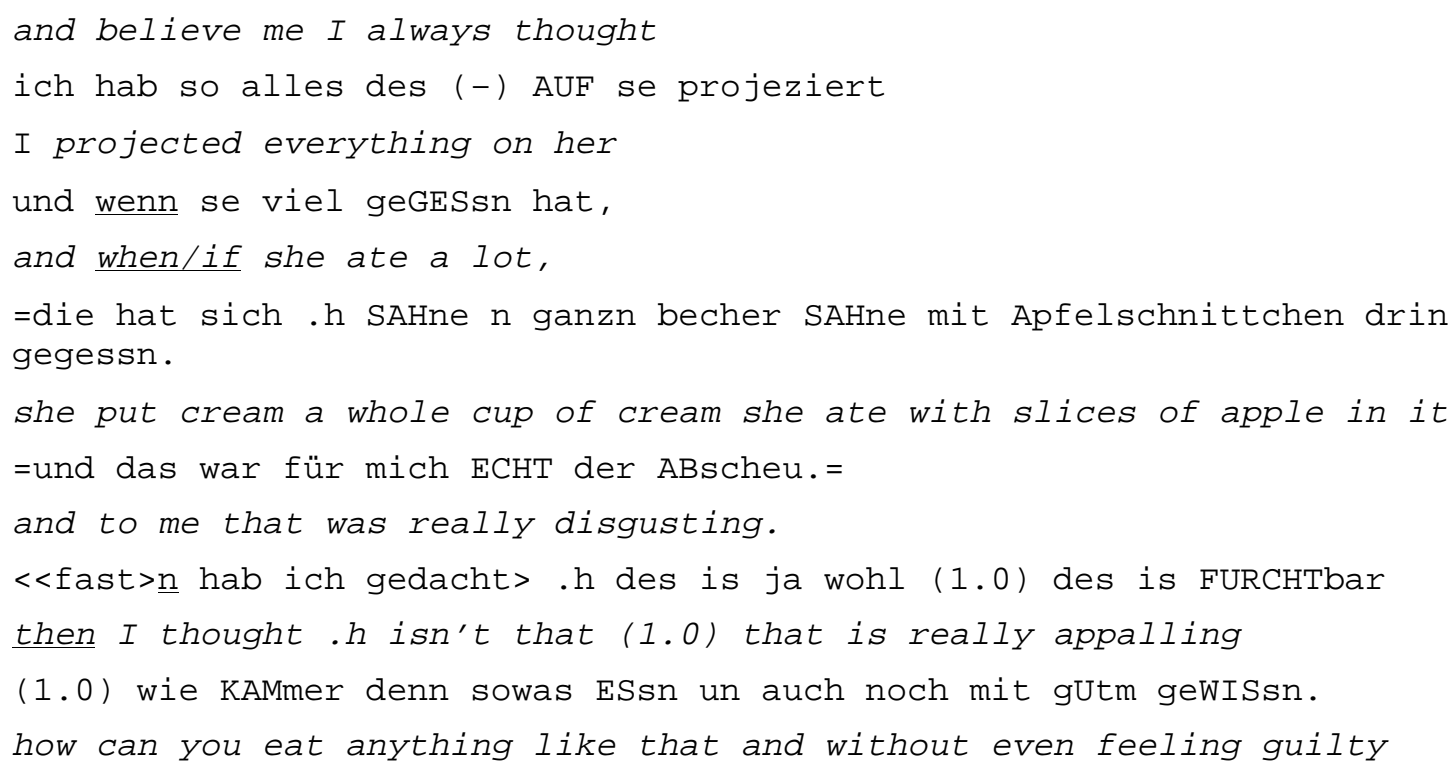

Once more, a speaker is involved in telling a story which in this case is supposed to show how she projected her own feelings of guilt for eating too much onto her flatmate. And once more, a wenn-clause is the first component of a syntactically cohesive turn construction which spans six intonation units. The speaker does not go into gestalt closure (apodosis) after the wenn-clause, but rather parenthetically includes information detailing the claim that the roommate ,ate a lot', and how she herself reacted to that emotionally. Only then does a (dan)n-clause follow which ties back to the initial part of the turn, where a story concerning a ,projection' (ich hab so alles des auf se projeziert) was announced.

There is only one legitimate way for a recipient to share (or rather, intrude into) the conversational space which a wenn-projection creates for the current speaker: by becoming a co-speaker herself, i.e, by collaboratively producing the gestalt-closing apodosis matching the already produced protasis (cf. Lerner 1991 and Ex. 11 above). First speakers may invite such co-construction by the recipient after the wenn-clause, as in the following example, in which delicate matters of re-negotiating an appointment are at stake:

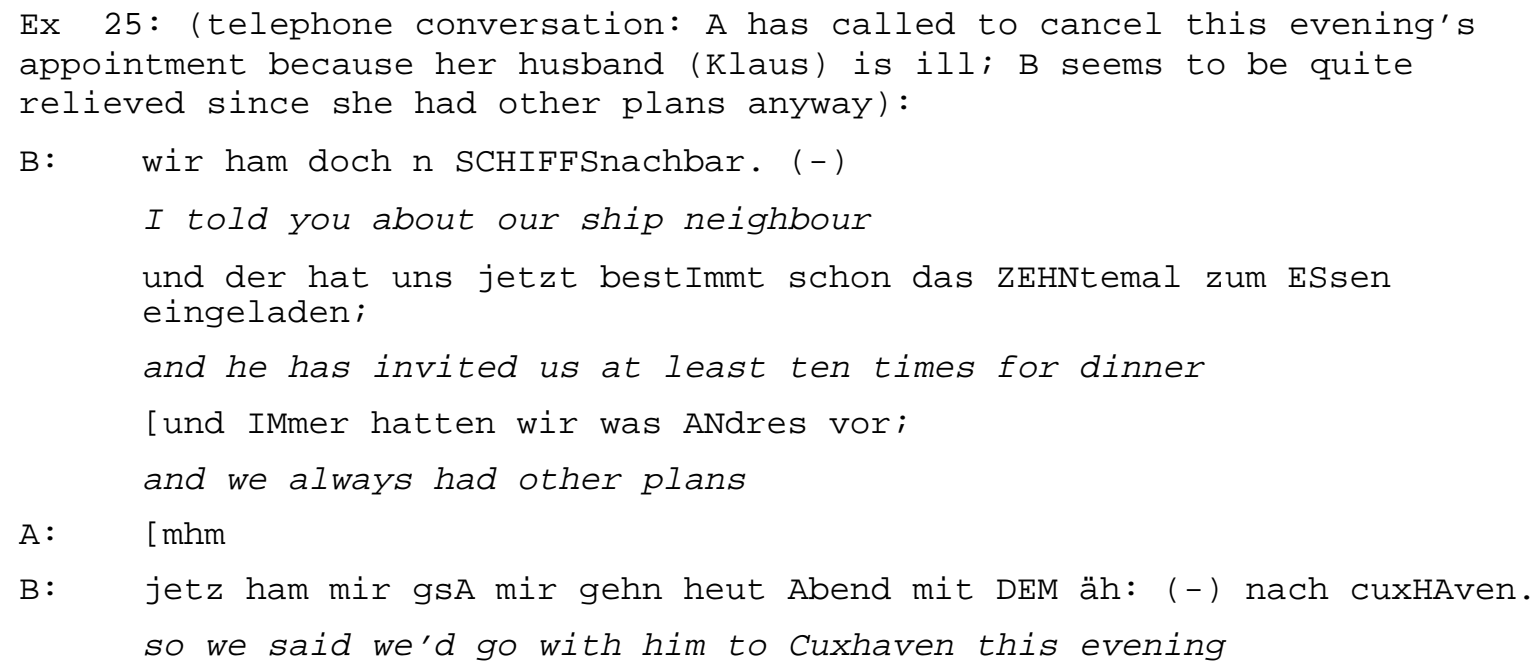




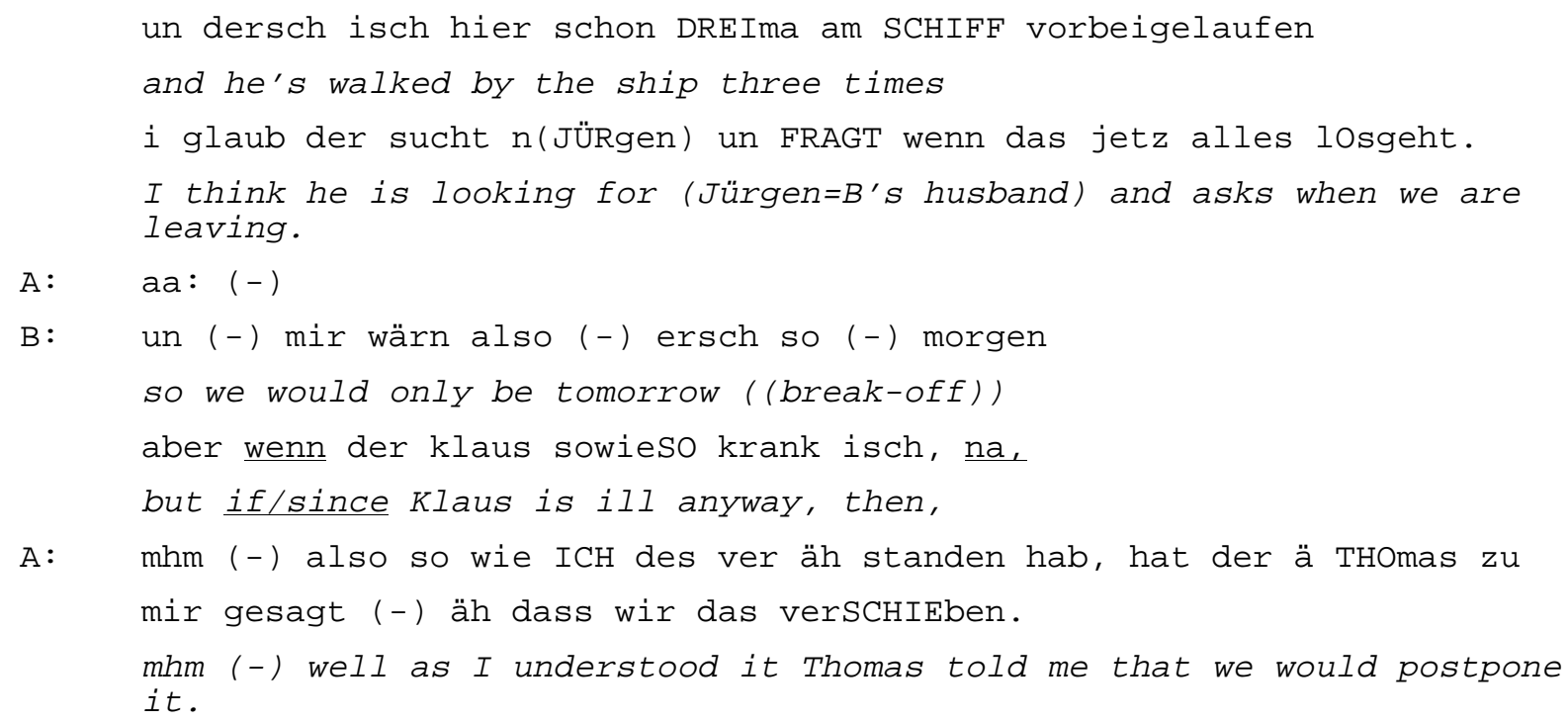

B starts out by underlining her social obligation to accept the ,ship-neighbour's' invitation to Cuxhaven this evening; she then produces two unfinished fragments which both point to the consequences of this fact for the meeting with A: und wir wären also erst so morgen... (,we would only be tomorrow...') - to be complemented by ,available', and a wenn-clause (,but since Klaus is ill anyway then...') which is broken off after the resumptive ,then' (na). Clearly, the consequent is highly predictable in this context: since "Klaus' is ill, the appointment for ,today" cannot be upheld. A suggests that B should draw this conclusion for herself, however, which would make it unnecessary for her to make the face-threatening act explicit. B indeed does so, but only indirectly: she does not pick up the syntactic frame suggested by A, i.e., she does not bring A's sentence to a conclusion, nor does she cancel the appointment herself but rather takes a third person's (Thomas') perspective.

What is responsible for most cases of the isolated wenn-clauses in the data are invitations for recipients to draw the inferences themselves which are suggested by speakers who have built up a ,mental space in a pre-positioned wenn-clause: in these cases, the invitation is not picked up (cf. Tab. (1)).

Both inserted material between protasis and apodosis and collaborative constructions pivoting around this transition suggest that there is some interactional work going on, and that, at least in a substantial subgroup of examples, the construction is not planned and executed as one whole, but rather develops in (at least) two steps.

\subsection{Why post-positioning at all?}

If pre-positioned wenn-clauses are both cognitively more ,natural' and interactionally more advantageous than post-positioned ones, why do the latter occur at all? Two reasons have 
already been mentioned in section 3: wenn-clauses may be used for expressing the temporal circumstances of an event, and since temporal adverbial clauses do not follow the preference for pre-positioning, wenn-clauses of this semantic type need not do so either. ${ }^{16}$ Secondly, it was shown that the absence of a front-field in questions and other verb-initial syntagms makes their post-positioning more likely. ${ }^{17}$ There are, however, other important reasons.

First of all, it may be asked if there are any further syntactic environments in which postpositioning is preferred or even necessary. There is indeed another construction in which the front-field is not available: that in which the wenn-clause plus subsequent clause are themselves embedded into a larger construction. The various types of embedding show different patterns with respect to the possibility of pre-positioning. As in Ford \& Thompson's English data (1986:359), final positioning is preferred „when a conditional clause occurs within a nominalization, an infinitive, or a relative clause“. Take, for instance, the following case of a relative clause:

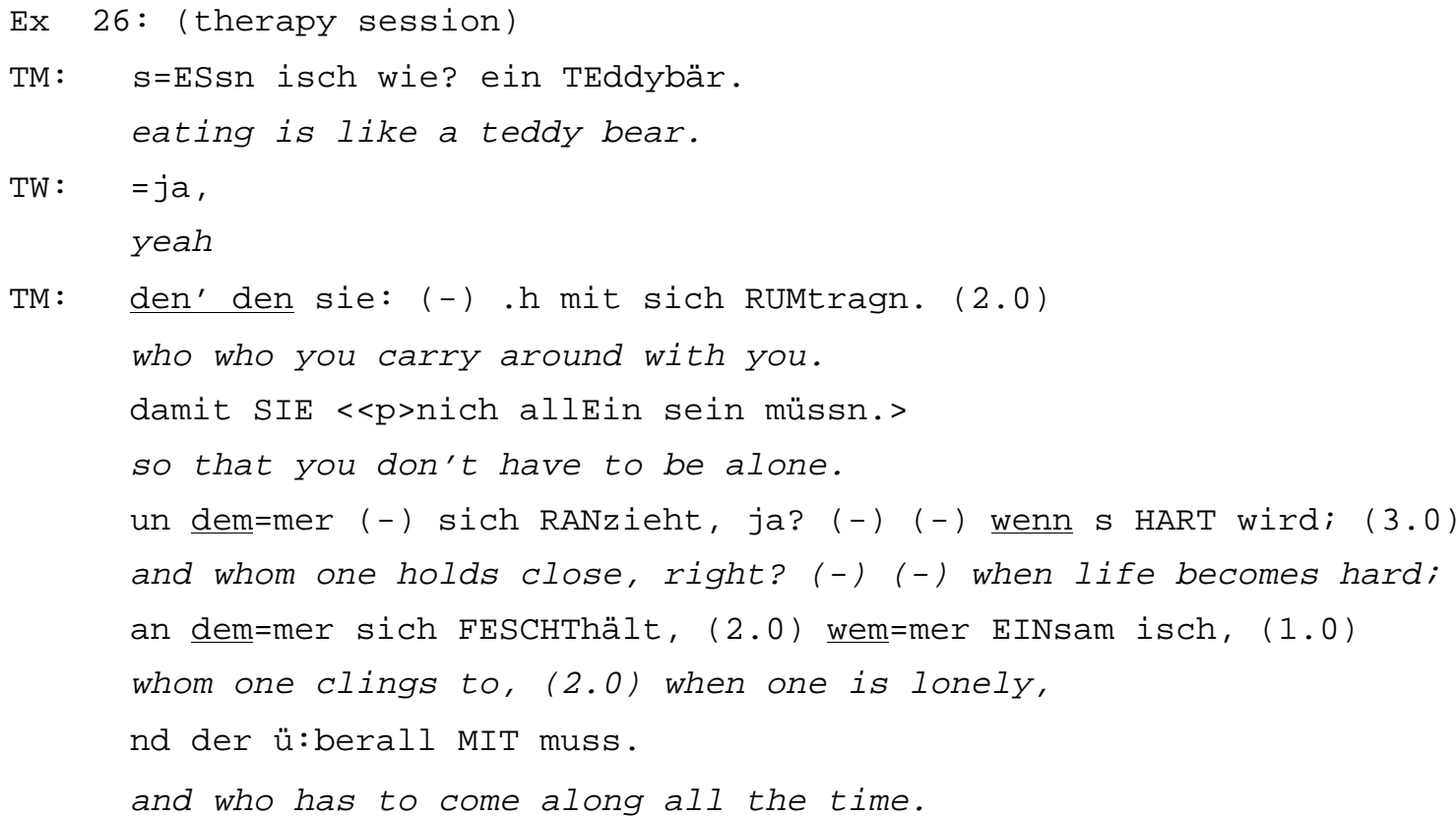

Both wenn-clauses in this extract are part of a relative clause introduced by an oblique relative pronoun, i.e., their matrix clause is itself subordinated, and therefore has verb-final syntax (cf. the placement of the finite verbs ranzieht and festhält). Here, the wenn-clause cannot be placed in front of the relative clause ("und wenn's hart wird den man sich ranzieht); pre-positioning would require a superordinated main clause instead of the relative

\footnotetext{
${ }^{16}$ This of course, leaves the question open why temporal adverbial clauses should behave differently from conditional ones - a question which requires an investigation of its own.

${ }^{17}$ For a similar remark on English, cf. Ford \& Thompson 1986:369.
} 
clause (und wenn's hart wird, zieht man sich den ran). ${ }^{18}$ The same applies to dependent clauses introduced by wie ,as', obwohl ,although', weil ,because', etc. which likewise do not allow initial wenn-clauses.

However, subordination by the most frequent complementizer dass (,that') shows a different pattern. Here, we frequently encounter initial placement of the pre-positioned wenn-clause BEFORE the complementizer dass:

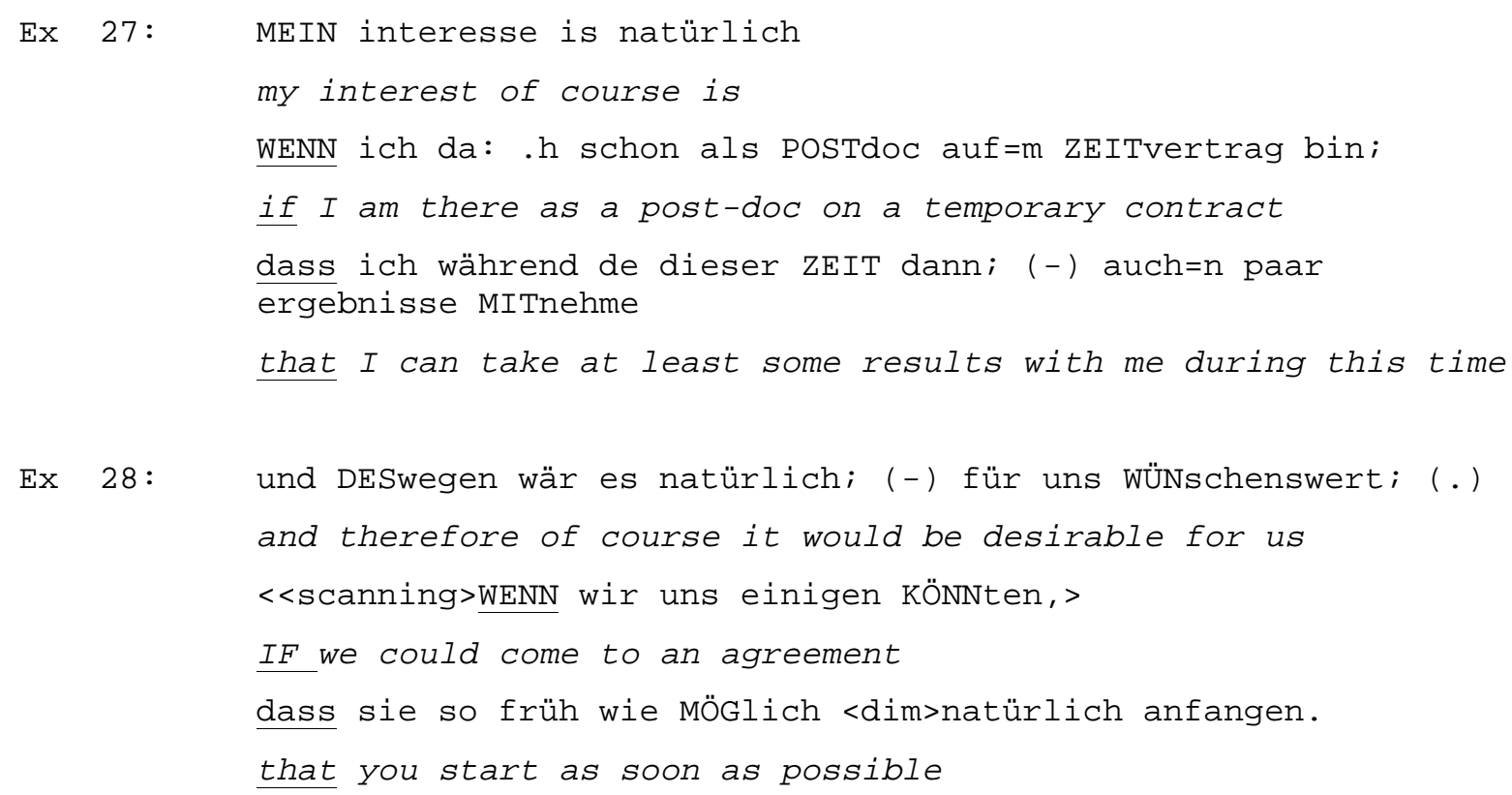

The additional stress on wenn in these examples may give us a clue to the origin of this construction; arguably, it underlines the semantic link between antecendent and consequent. Fronting the wenn-clause to a position before the dass-complementizer may be another way of focussing on the semantic link established by wenn. ${ }^{19}$ Note in passing that the fronting of the wenn-clause renders its scope ambiguous both in (27) and (28): it may or may not include the initial phrases mein Interesse ist natürlich/ ...wäre es natürlich für uns wünschenswert (i.e.: , of course, if I am only there as a post-doc on a temporary contract, then my interest is to take at least some results with me' and if we could come to an

\footnotetext{
${ }^{18}$ In some cases, however - though not in (26) with its oblique relative pronoun - , the wenn-clause can follow the relative pronoun (das Essen ist wie ein Teddybär, der, wenn es hart ist, immer bei Ihnen ist, und der, wenn man einsam ist, zum Festhalten da ist). But here we are dealing with parenthetical placement in the middle field of the sentence; this is exceedingly rare in spoken German. ${ }^{19}$ Of course, wenn is not always stressed in fronted wenn-clauses. Cf. the following example: ich (.) hab (-) FÜNF jahre lang an der schule franzÖsisch geHABTh, mir fEhlts eigentlich an (.) PRAxis, .h aber: (-) ich bin überzEUGT davon, =wenn ich: eh eh ÖFters mal die geLEgenheit hätte zum beispiel in ERANKkreich, eh mich aufzuhaltn, .hh dass des: (-) eh SICherlich Ausbaufähig is.

I had French at school for five years, actually I'm lacking practice, but I'm convinced if I on occasion had the chance to spend some time for instance in France, that I could work on it.
} 
agreement it would of course be desirable for us that you start as soon as possible، respectively). ${ }^{20}$

In addition to these syntactic constraints, there are semantic-syntactic reasons for postpositioning wenn-clauses. In particular, wenn-clauses in complement function are usually postpositioned (cf. (13) and (14) above). As a rule, the main clause contains an evaluative two-place predicate, with the wenn-clause expressing the proposition which is evaluated (as in Ex. 14: vielleicht ist die mutter ga:nz FROH wenn sie hört dass ihr SOHN ... eine FREUNdin hat). ${ }^{21}$ The opposite serialization is not unacceptable, particularly if an anaphoric pronoun is used to indicate the syntactic position in the main clause in which an argument is lacking (wenn sie hört, dass ihr Sohn eine Freundin hat, ist die Mutter vielleicht ganz froh $D A R U ̈ B E R$ ); nevertheless, it is very rare. The dominant pattern obviously parallels that of dassintroduced complement clauses which can, but rarely do, precede the main clause as well. Complements make up ca. $25 \%$ of all the post-positioned wenn-clauses in the spoken materials investigated.

Finally, and most importantly, post-positioning of wenn-clauses is linked to the pragmatic status of the proposition they express, and to the interactional possibilities this position opens up both for the speaker and the hearer. As outlined in section 1, final subordinated clauses in German are added onto an already complete syntactic structure. They are therefore a straightforward means for expanding a syntactic gestalt, and thereby the turn-at-talk. This is particularly obvious in cases where syntactically complete syntagms preceding the wennclause are marked as terminal by intonation, e.g. by a pitch fall to the speaker's base line (full stop in the transcription); the wenn-clause then appears as an afterthought, or epexegesis (cf. Auer 1991):

Ex 29: (hypothetical talk about a situation in which two people are in
conflict over where to put the cup for the coffee; B is asked to mediate)

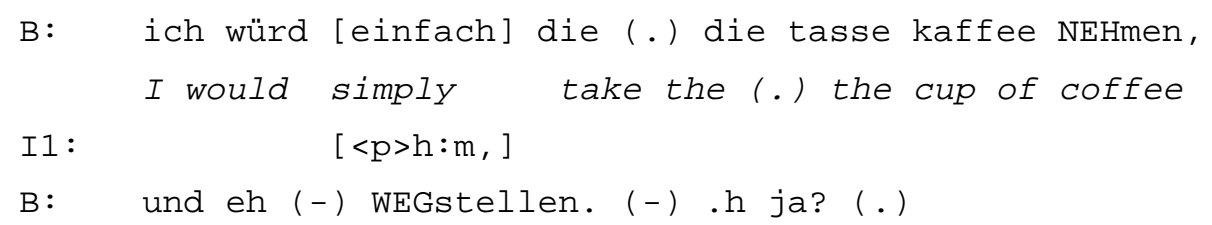

\footnotetext{
${ }^{20}$ The tendency to place the wenn-clause early in dependent constructions is also evidenced by the fact that parenthetical placement immediately after dass is frequent (cf. Note 18). Often, a second, resumptive dass is added at the beginning of the consequent:

kAnnst du ihm vielleicht (-) AUSrichten dass ich ANgerufn habe?

could you perhaps tell him that I called?

und dass wenn er mit dem trelitz gespRochen hat über meine prüungk,

and that if he has talked to Trelitz about my exams,

dass er sich dann irgenwie=mal=GANz kurz bei mir mElden soll?

that he should give me a quick ring some time?

${ }^{21}$ The same was found in English conversations by Ford \& Thompson 1986:368.
} 


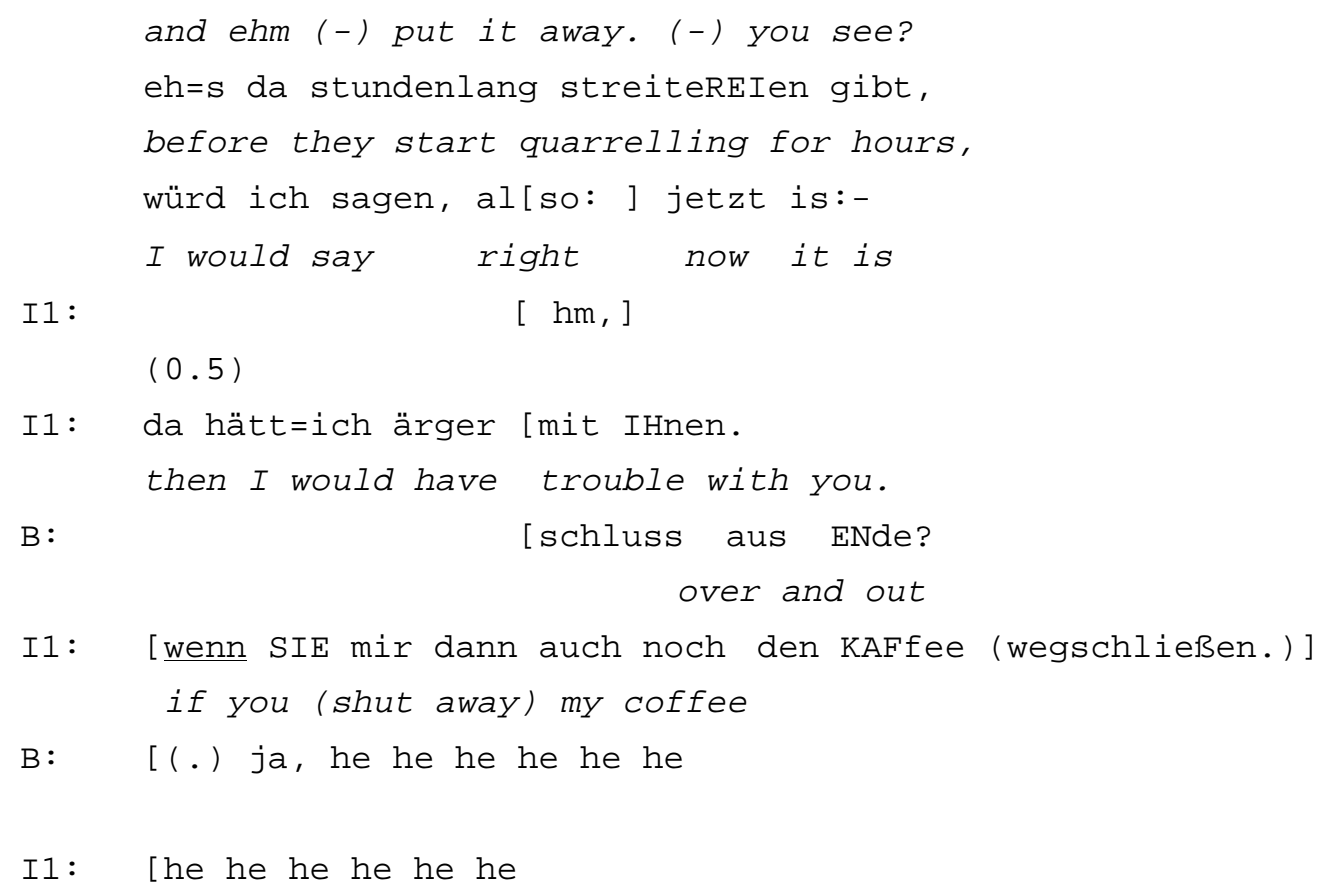

At a point where B has already suggested simply ,taking away" the disputed coffee cup, but is in the middle of a syntactic construction elaborating on this proposal (eh's da stundenlang Streiterei gibt würde ich also sagen: Schluss, aus, Ende) 11 intervenes during an intra-turn hesitation pause to refute this solution: ,if you do that, there would be trouble between the two of us' (i.e. between the mediator, B, and one of the two people quarrelling, i.e. himself). The utterance is linked to B's proposal by the initial anaphoric da; it is semantically and syntactically complete, and being marked by a final fall, it certainly is a candidate for a complete turn. However, B does not pick up this refutation, but continues with the production of the unfinished syntagm in another piece of simultaneous talk. Sequential structure and temporal development are now out of phase: a response has been produced to an utterance which is still in need of being completed, and is only completed after the response. In this context, I1's following wenn-clause, syntactically expanding an already complete turn/syntagm, can be seen as a skillful way of re-aligning sequentiality and timing: it reinstantiates I1's refutation of B's proposal without repeating it, by retrospectively transforming a simple construction into a hypotactical one with a post-positioned adverbial clause. Semantically, this expansion adds nothing new: it just restates what $B$ herself has said before.

The possibility of such an expansion is not only available to the speaker but also to the recipient, of course, who may become a co-speaker and co-producer of the emerging syntactic pattern by adding a wenn-clause himself/herself:

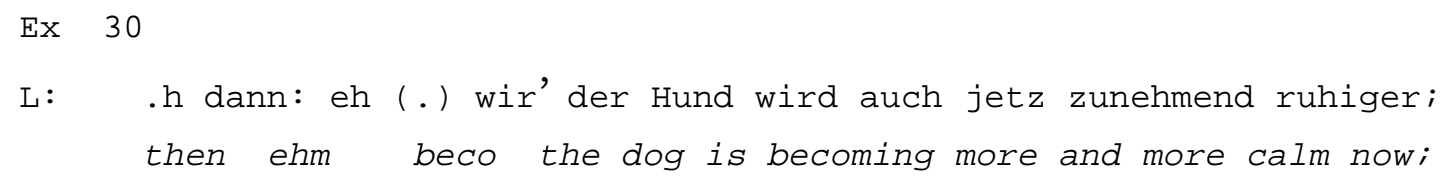




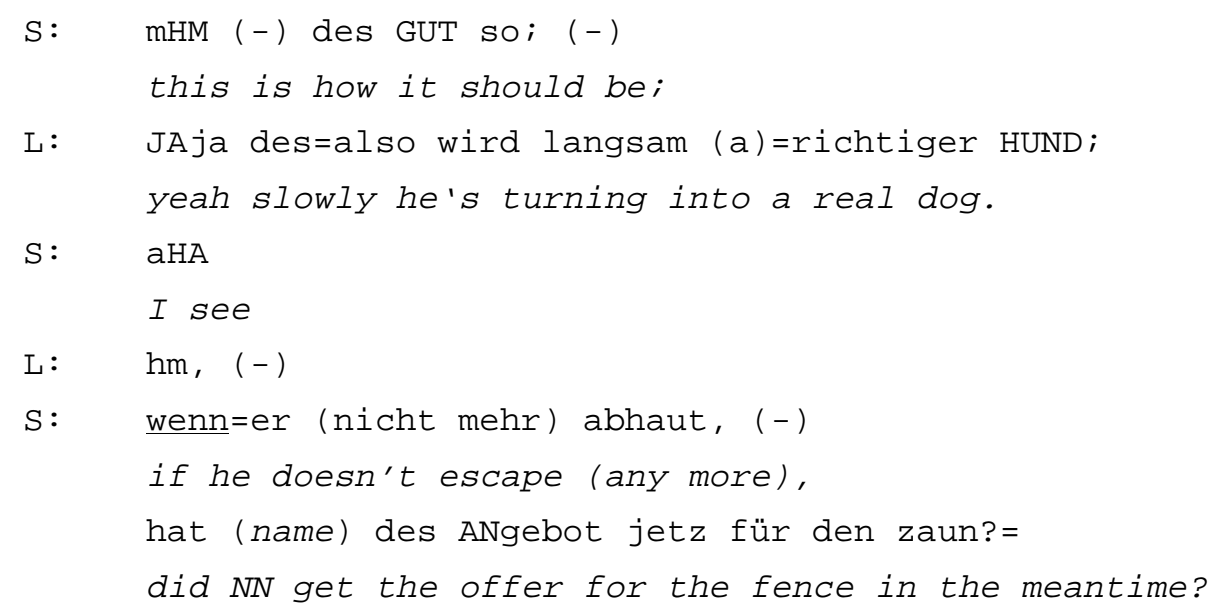

So it is not only the transition between a wenn-clause and its subsequent main clause which is sensitive to turn-taking, but also the inverse transition between a (main) clause and its subsequent wenn-clause. But obviously, there is an important difference: while in the first case an open syntactic projection is in play, in the second case the first speaker has already come to an orderly completion of the sentence/turn.

Post-positioned wenn-clauses thus offer the possibility not only of expanding a turn, but also of expanding a sentence by adding a post-field constituent. At least example (29) ${ }^{22}$ also points to an important pragmatic feature of such expansions: its low information value. Indeed, this applies to a very large number of post-positioned wenn-clauses. Often it is the whole previous text which functions to build up the ,mental space that is necessary to come to the conclusion expressed in the main clause, while the post-positioned wenn-clause only summarizes this preceding text, sometimes slightly changing the focus. In (31), the introductory adverbial insofern explicitly establishes this resultative link between pre-text and conclusion, while the post-positioned wenn-clause just repeats what is known from the previous conversation anyway (the wenn-clause is factual here):

Ex 31: (lafter a long discussion of the applicant's career aspirations in the bank, and an equally long description of the branch bank in stralsund and its sophisticated private client service, which seems to match these wishes))

((..)) das HAM wir alles in stralsund, also insofern, (-) eh wäre das=ne we've got all that in stralsund, so in that regard, this would be an ideal ideAle (-) STELle, (-) wenn sie (-) praktizlEren wollen im position if you want to be a trainee in the sales department. in clientverTRIEBSbereich. im KUNDdennahen bereich.

oriented business.

${ }^{22}$ In other-speaker produced post-positioned wenn-clauses this does not always hold, since second speakers may choose this way of intimately linking their speech to a preceding syntactic pattern but nonetheless produce unexpected and even contradictory information under this ,disguise: 
As in other, similar cases of low-relevance wenn-clauses in final position, the front-field is used here for a connecting (anaphorical) adverbial, which is preferentially placed in sentence-initial position, where its indexical meaning is most easily processed. Since only one constituent may be placed in the front-field, this position is not available for the wennclause any longer.

Since post-positioned wenn-clauses are often of low pragmatic relevance, upgrading their informational value requires special means; a standard technique for doing so is the use of focussing particles such as (stressed) auch, nur or dann, or a combination of these. In this case, it is the focussing particle which projects syntactically: it requires a constituent to follow which is in its scope. Therefore, wenn-clauses such as the following cannot be treated in the same way as post-field wenn-clauses in general: they do not expand an already complete syntactic pattern but rather close a gestalt projected by the particle.

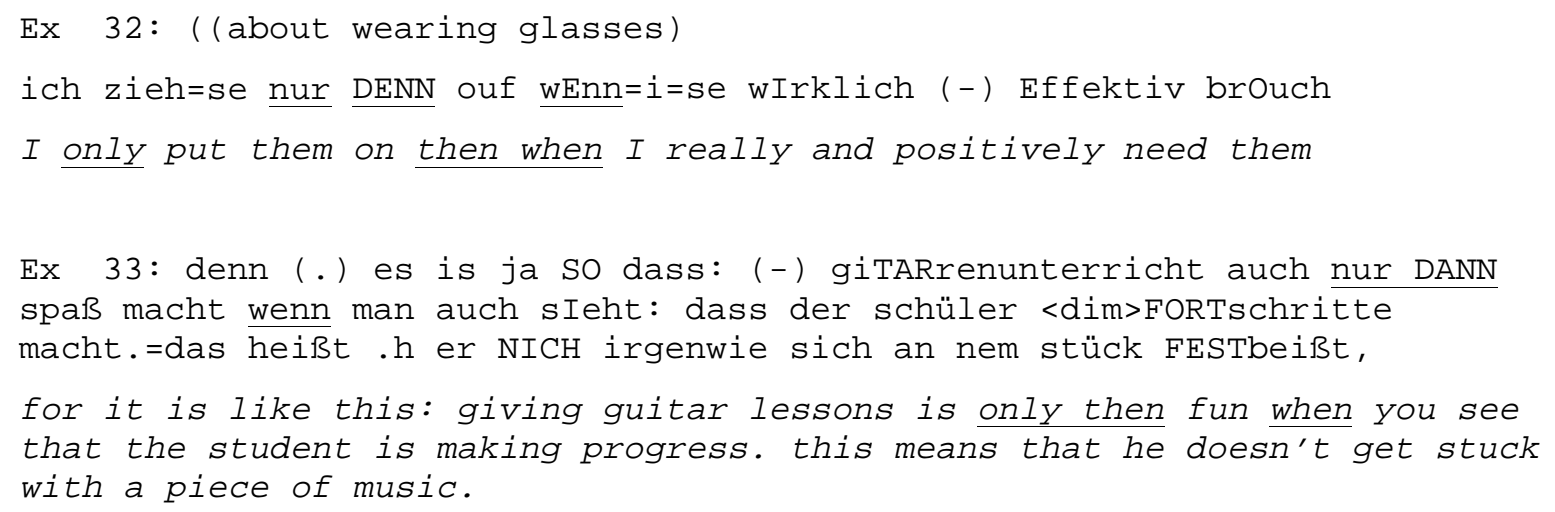

Ex negativo, the necessity of using such focussing particles in order to upgrade the following wenn-clause to rhematic status is evidence for the (sub)thematic status which wenn-clauses usually have in the post-field.

\section{Pre- and post-positioning of wenn-clauses in written German}

In the last sections, it has been shown that wenn-clauses are preferentially pre-positioned with respect to their main clauses in spoken German, and that this serialisation has a number of cognitive and interactional advantages. It has also been shown that the more marked structure, i.e. post-positioned wenn-clauses, which does occur in about a third of all instances, has its own specific contexts of usage. These are partly due to (a) syntactic constraints on pre-positioning in superordinate clauses without a pre-field or in which two complementizers occur in adjacent position; partly to (b) turn-taking (afterthought position); partly to (c) semantic-syntactic reasons (wenn-clauses in complement function are postpositioned); and partly to (d) pragmatic reasons (post-positioned dependent clauses are thematic or subthematic, unless focussing particles indicate the contrary). 
In written German, wenn-clauses are generally less frequent than in spoken discourse, a finding which contradicts the frequent claim that spoken language avoids syntactically complex constructions. Fig. (4) shows the frequencies of wenn-clauses per 100 words in the corpus of spoken language used above, and in a corpus of written language, taken from the newspapers DIE ZEIT (politics section) and Frankfurter Allgemeine Zeitung (culture section). ${ }^{23}$ Transcriptions of conversational speech were regularized in order to make a comparative computer-based word-count possible. ${ }^{24}$

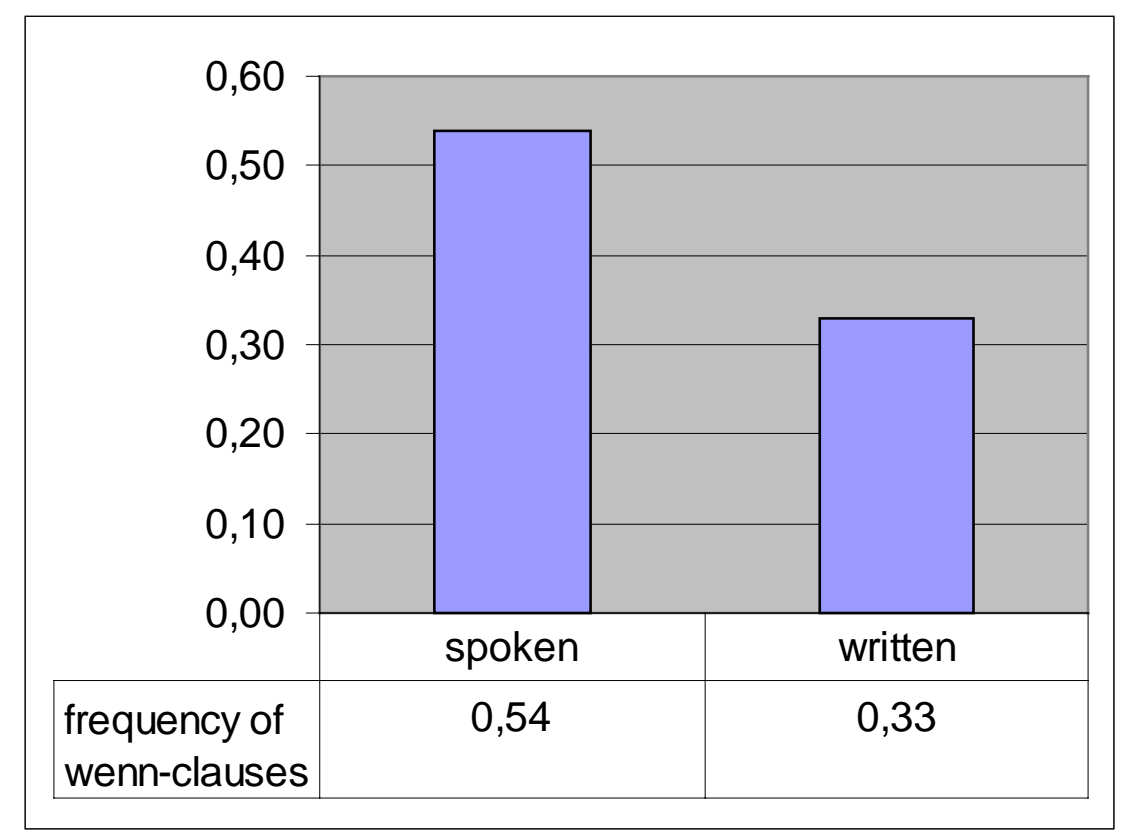

Fig. 4: Frequency of wenn-clauses in spoken and written German per 100 words

As Fig. 4 shows, every $186^{\text {th }}$ word is wenn in our spoken corpus on an average, but only every $300^{\text {th }}$ word in our written texts. Once more, this finding is in line with comparative work on written and spoken English (Ford \& Thompson 1986, 354: 0.72 vs. 0.46; similarly: Beaman 1984 and Biber 1986), but also with previous work on German (Leska 1965, 450).

There are of course also qualitative differences between the wenn-clauses used in the two corpora; in particular, certain rather idiomatic patterns (constructions) seem to be more or less exclusively used either in spoken or written language. For instance, the reduced wenn(dann)-constructions of spoken German (cf. section 2.2. above) do not occur in the newspaper corpus, while, on the other hand, the topicalizing causative construction wenn $p$ dann (deswegen), weil $q$ (,if $p$, then that is because of $q^{c}$ ), as in (34), seems to be used exclusively in writing

\footnotetext{
${ }^{23}$ More exactly, the corpus included the F.A.Z. Feuilleton-Glossen from Jan 8, 1993 (Ausgabe Nr. 6) to Dec 31, 1993 (Nr. 304) and DIE ZEIT politics section of Dec 30, 1994 (No. 1) to Feb 17, 1995 (Nr. 8).

${ }^{24}$ See Appendix for an example.
} 
Wenn wir das Leugnen von Auschwitz, anders als das Leugnen der

kopernikanischen Wende, unter Strafe stellen, dann deswegen, weil es uns nicht nur hypothetisch angst macht.

If we punish the denial of Auschwitz, and not the denial of the Copernican revolution, then that is because it does not make us feel afraid only hypothetically.

Also, and contradicting received wisdom according to which written language is more logical and more explicit, we find instances of wenn as a conjunction in the newspaper texts, with semantics which are exceedingly vague, as for instance in (35):

Ex 35: (F.A.Z 19.06.1993, S. 27 / Nr. 139)

Aber wenn zum stets und inständig angestrebten "Weltniveau" der DDR die Stellvertreterschaft des überragenden, fortschrittlichen, darin sogar selbst "bürgerlichen" Kulturerbes gehörte, dann äußert sich nun das Aufschließen zur Weltoffenheit seltsam kleinmütig.

But if the representation of the outstanding and progressive cultural heritage, one which includes even the "bourgeois", belonged to the ever and urgently sought after "international standard" of the GDR, then growing into cosmopolitan open-mindedness expresses itself rather timidly nowadays.

Here, the wenn-dann construction seems to vaguely express something between adversativity and concessivity.

However, these differences only affect a relatively small number of examples and are not directly linked to the positioning of the wenn-clause. The important question for the present discussion is rather whether the preference for pre-positioning of wenn-clauses is also to be found in written German (as it is in written English, cf. Ford \& Thompson 1986 ${ }^{25}$ ). Fig. (5) shows that this is not the case:

\footnotetext{
${ }^{25}$ The written corpus used by Ford \& Thompson consisted of philosophical essays, a professional text for automobile mechanics, and a personal narrative account (1986:355). The preference for prepositioning held for all these sources.
} 


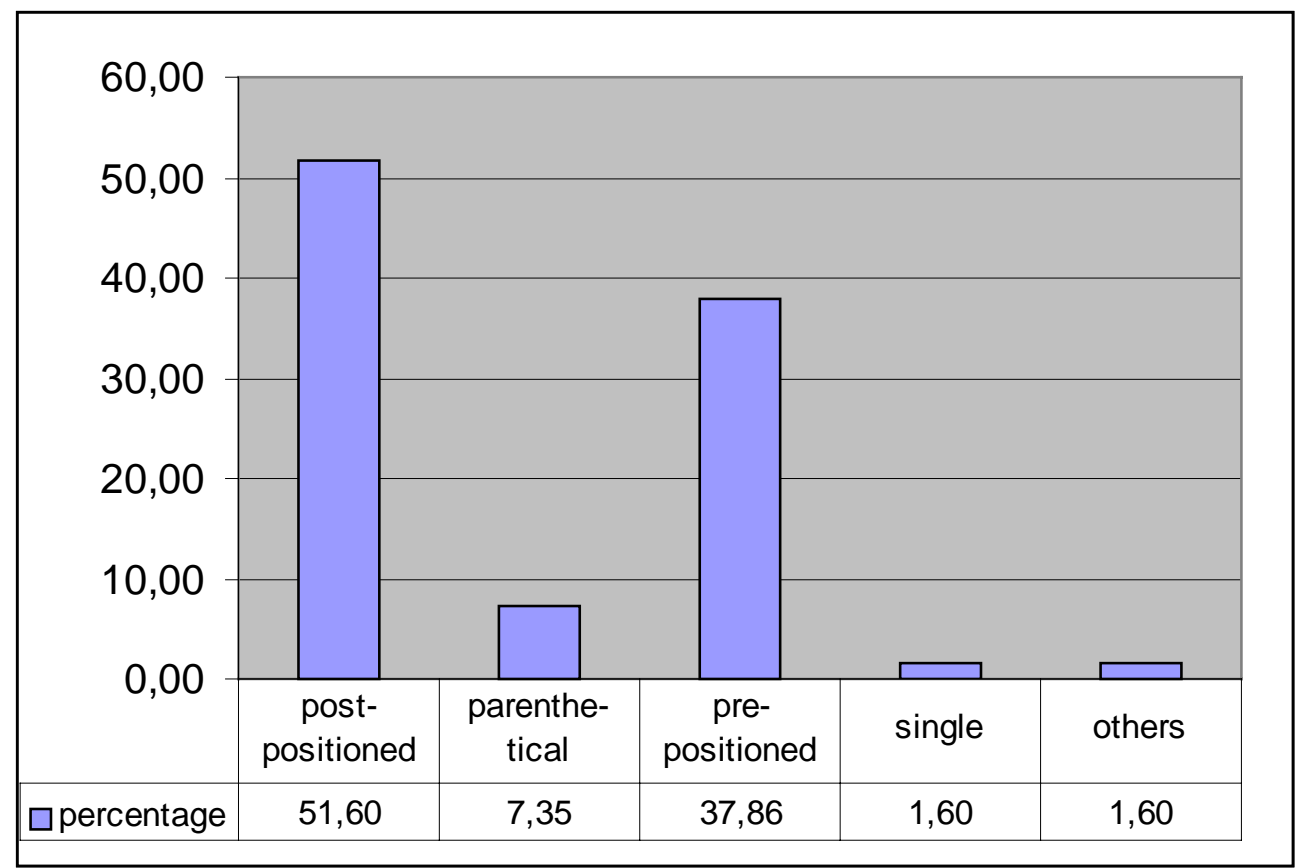

Fig. 5: Percentage of post- and prepositioned wenn-clauses in written German ( $n=626)$

In the written materials, post-positioned wenn-clauses are almost one and a half times more frequent than pre-positioned, ones while the opposite ratio is found in the spoken material. ${ }^{26}$ As would be expected, the number of integrative pre-positioned wenn-clauses is higher than in conversational language, and both the number of non-integrative and resumptive ${ }^{27}$ structures is markedly reduced (cf. Fig. (6)).

\footnotetext{
${ }^{26}$ A separate count for the two newspapers shows that the quantitative results are identical.

${ }^{27}$ The resumptive particle is dann in 46 cases and so in 16 cases. Dann and so are not freely interchangeable; in particular, so can be used with concessives (introduced by auch/selbst wenn), while dann cannot. Cf.: Auch wenn das Abgeordnetenhaus erst im Herbst, voraussichtlich am 22. Oktober, gewählt wird, so hat mit der Urabstimmung schon der Wahlkampf begonnen. (,Even though parliament will not be elected until autumn, probably on October 22, SO the electorial campaign has already begun with the strike ballot.')
} 


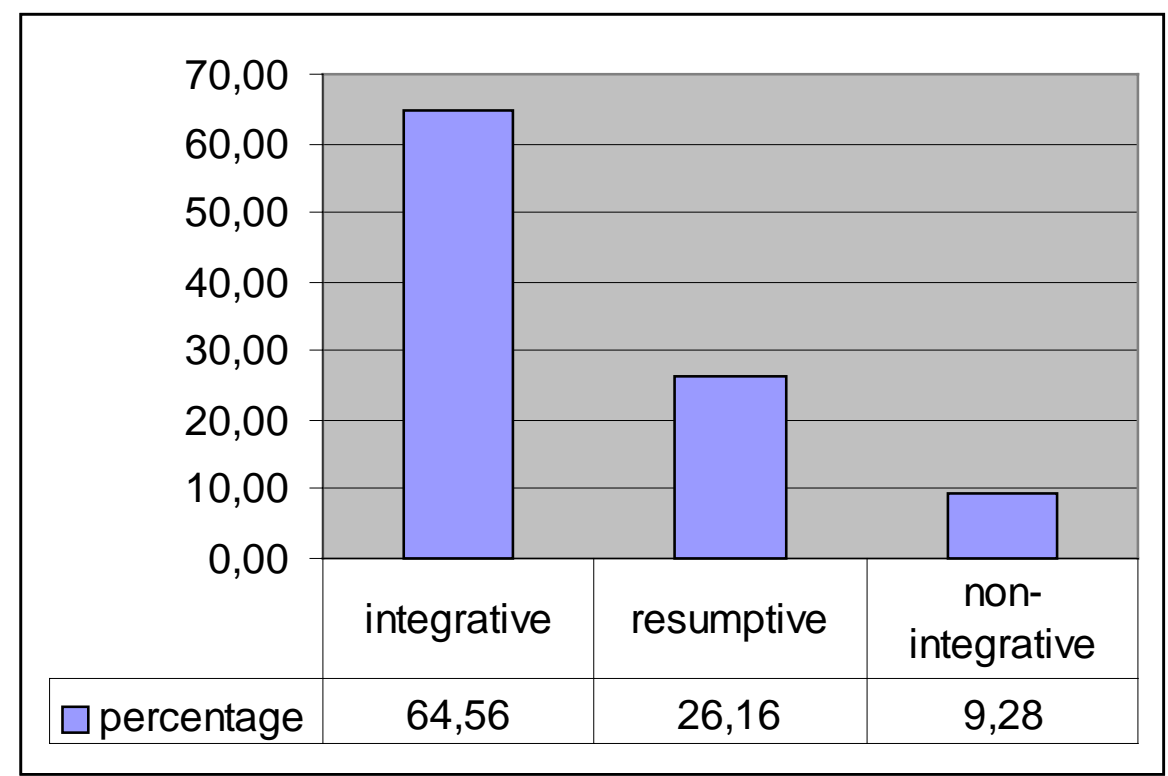

Fig. 6: Percentage of integrative, resumptive and non-integrative wenn-clauses in written German $(n=237)$

Fig. 7 shows that the preference for post-positioning is only slightly less pronounced in unambiguously conditional wenn-clauses than in unambiguously temporal ones.

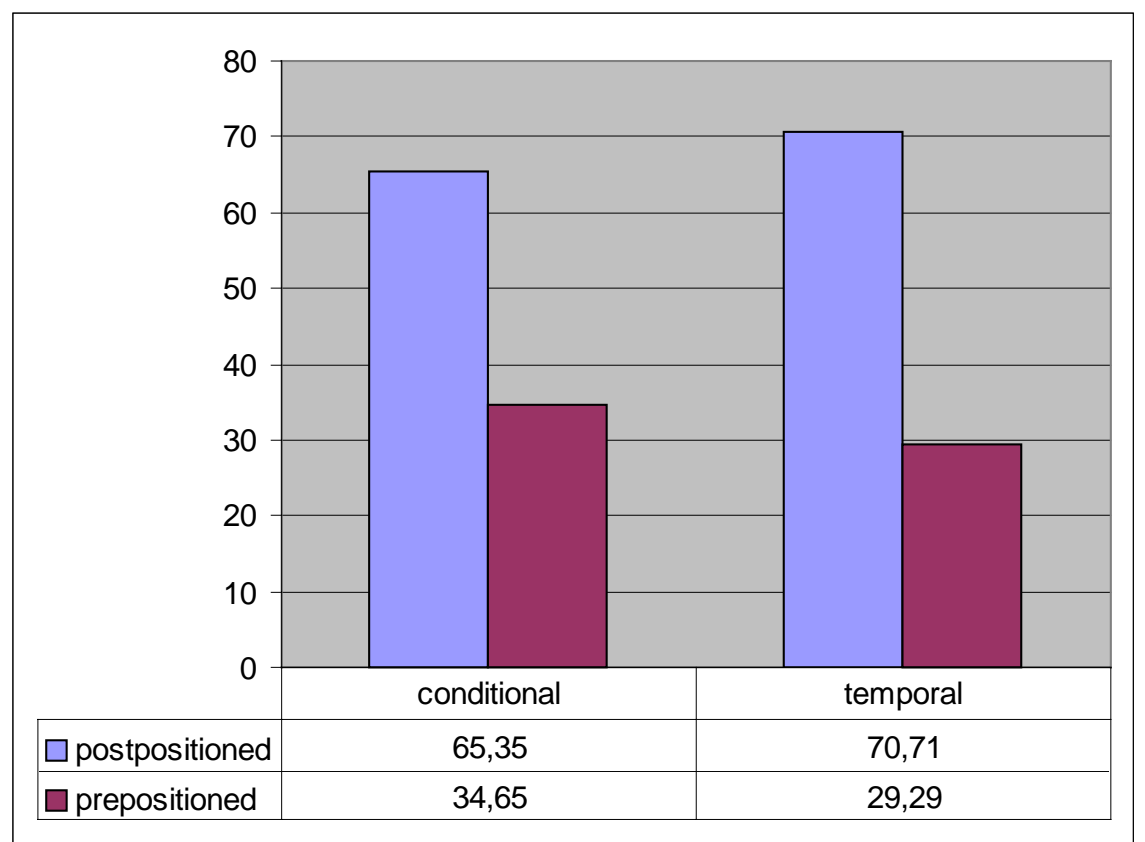

Fig. 7: Pre- and postpositioning of temporal vs. conditional wenn-clauses in written German ( $n=301)$

What could be the reason for this reversal of preferences for post- and pre-positioning in written German compared to spoken language? Three factors seem to be primarily responsible for it. First, the number of (almost exclusively final) wenn-clauses with a preceding focus particle in the main clause is about eight times as high in the written as in the spoken material ( 40 vs. 5 occurrences). An example is: 
Danach dürfen Frauen ungewollte Schwangerschaften in den ersten drei Monaten nur beenden, wenn sie sich vorher haben beraten lassen: in einer Beratungsstelle und vom abtreibenden Arzt.

Accordingly, women may only terminate an unwanted pregnancy during the first three months if they have undergone counselling: in an advice centre and also by the physician who does the abortion.

Secondly, although embedded wenn-clause plus main clause constructions are not more frequent in the written than in the spoken material, all 52 wenn-clauses of this type are postpositioned, while a majority of them (34 of 54, all of which are embedded into dassconstructions) are pre-positioned in the spoken materials. In other words, fronting of wennclauses before the embedded matrix clause such as in (27) or (28) does not occur in the newspaper texts.

Finally, one of the important reasons outlined above for frequent pre-positioning in interactional language use is simply not applicable to writing: this is the need for the speaker to claim conversational space for the production of a larger turn, through projecting syntactically beyond the current clause. Instead, another factor becomes relevant: in writing, the wenn-clause may become so complex that processing it would become difficult even in reading if it was pre-positioned with respect to its main clause; cf. for instance:

Ex 37: (DIE ZEIT Nr. 03 13.01.1995)

Und man denkt an Talleyrands Feststellung: "Hochverrat ist eine Frage des Datums", wenn man sich daran erinnert, daß Hans Modrow in einer Phase als Reformer und Hoffnungsträger galt, aber in der nächsten für schuldig erachtet wurde, weil er mitverantwortlich war für das DDR-System.

And one thinks of Talleyrand's statement: "High treason is a question of the date" when one recalls that Hans Modrow was regarded as a reformer and as a source of hope in one phase, but that he was found guilty in another, because he shared responsibility in the GDR political system.

Neither of these reasons for post-positioning in written German can explain the difference between the English and the German results, of course. Why should these same reasons not lead to a preference for post-positioning in written English as well? If one was looking for a structural explanation, one would probably try to find an answer based on the most prominent difference between English if- and German wenn-clauses, i.e. the semantic ambiguity of the latter. For instance, it might be argued that since wenn can often be interpreted either conditionally or temporally, German newspaper journalists try to disambiguate their sentences by using other, strictly conditional conjunctions instead, such as falls, im Falle dass, für den Fall dass, sofern or soweit. However, this hypothesis receives little empirical support in my data: not only are these conjunctions very rare in the newspaper texts (a total of 31 tokens!), they also fail to show a positional distribution different from that 
of wenn (6 initial vs. 17 final tokens, with 8 parentheticals). ${ }^{28}$ Another possibility to express conditionality in German which is not available in present-day English (apart from peripheral cases) is inversion (as in: kommst $d u$ zu spät, bestraft dich das Leben = wenn $d u$ zu spät kommst, dann bestraft dich das Leben ,if you are late, you will be punished by life"). This possibility is almost never used in spoken German because of its bookish and high-register connotations but ist occurrence cannot be excluded in rather conservative newspapers such as DIE ZEIT and F.A.Z.; and since the distribution of pre- and post-positioned conditional clauses with inversion is unknown we cannot exclude a balancing effect, for instance due to a preference for pre-positioning in this case. Since this syntactic pattern can only be quantified in syntactically labelled corpora, there is no possibility to test this hypothesis in a straightforward way in our materials. However, preliminary analysis of some texts suggests that inversion hardly occurs in newspapers. Alternatively, one might look for a non-structural explanation which would locate the reason for diverging English and German patterns on the textual level, possibly in the stylistic preferences of English and German text composition. The matter clearly awaits further investigation.

\section{Conclusion}

In this paper, I have looked at the placement of German wenn-clauses in spoken and written texts. Various explanations for the general quantitative results - i.e., that spoken German prefers pre-positioning, written German post-positioning - have been presented and discussed on the basis of individual conversational contexts in which wenn-clauses occur.

The general conclusion of this study is that the supposed parallel between ,left" and ,right" in syntax (suggested by parlances such as ,left extraposition“ vs. ,right extraposition', or ,leftadjoined' vs. ,right-adjoined') is fundamentally mistaken when applied to spoken syntax; in speaking, there is no ,left' and ,right', but only, earlier' and ,later'. At least for an approach to syntax which takes the in-time (,on-line') emergence of (particularly) oral language units seriously, what is dealt with first and what is taken care of later cannot be seen as a decision between two logical equivalents (as between ,right' and ,left'). Rather, it involves one of the most basic and far-reaching decisions a speaker can make, with all kinds of cognitive, interactional and structural repercussions. ${ }^{29}$

\footnotetext{
${ }^{28}$ Of the 15 tokens in the spoken material, the three positions were about equally distributed.

${ }^{29}$ For a similar argument, cf. Thompson 1985.
} 


\section{Bibliography}

Auer, P., 1991, Das Ende deutscher Sätze - Rechtsexpansionen im deutschen Einfachsatz. ZGL 1991, 139-157

Auer, P., 1996, The pre-front field in spoken German and its relevance as a grammaticalization position, Pragmatics (Special issue, eds. Joh. Wagner \& Cecilia Ford), Vol. 6, No. 3, 295-322.

Biber, Douglas, 1986, Spoken and written textual dimensions in English: Resolving the contradictory findings. Language 62, 384-416.

Couper-Kuhlen, Elizabeth, 1999, Varieties of conditionals and their emergence in discourse. In: A. Lahiri, A.Patschovky \& Ch. Schwarze (eds), Issues in Interdisciplinary Research on the Lexicon $=$ Working Paper No 99, University of Constance, Fachgruppe Sprachwissenschaft, 89-130.

Dancygier, Barbara \& Sweetser, Eve, 1996, Conditionals, distancing, and alternative spaces. In: A. E. Goldberg (ed), Conceptual Structure - Discourse and Language. Standord: CSLI Publications, 83-98.

Eisenberg, Peter, 1994, Grundriß der deutschen Grammatik. Stuttgart: Metzler.

Fauconnier, Gilles, 1985, Mental Spaces. Cambridge: UP.

Fillmore, Charles J., 1990, Epistemic stance and grammatical form in English conditional sentences. In: CLS 26, University of Chicago, 137-162.

Ford, Cecilia E., 1993, Grammar in Interaction. Adverbial Clauses in American English Conversations. Cambridge: UP.

Ford, Cecilia, E., 1997, Speaking conditionally: Some contexts for if-clauses in conversation. In: A. Athanasiadou (ed.), On Conditionals Again. Amsterdam: Benjamins, 387-413.

Ford, Cecilia E. \& Thompson, Sandra A., 1986, Conditions in discourse: a text-based study from English. In: E. Traugott et al. (eds), On Conditionals. Cambridge: UP, 353-372.

Greenberg, J.H., 1963, Some universals of grammar with particular reference to the order of meaningful elements. In: Greenberg, J.H. (ed.), Universals of Language, Cambridge: Mass., MIT-Press, 73- 113.

Günthner, Susanne, 1999, Wenn-Sätze im Vor-Vorfeld: ihre Formen und Funktionen in der gesprochenen Sprache. Deutsche Sprache 27/3, 209-235.

Haiman, John, 1978, Conditionals are topics. Language 54, 564-89.

König, Ekkehard, 1985, Where do concessives come from? On the development of concessive connectives. In: J. Fisiak (ed.), Historical Semantics. Berlin: de Gruyter, 263-282.

König, Ekkehard \& van der Auwera, Johan, 1988, Clause integration in German and Dutch conditionals, concessive conditionals, and concessives. In: J. Haiman \& Sandra A. Thompson (eds), Clause Combining in Grammar and Discourse. Amsterdam: Benjamins, 101-133.

Köpcke, Klaus-Michael \& Panther, Klaus-Uwe, 1989, On correlations between word order and pragmatic function of conditional sentences in German, J. Pragm. 13, 685-711.

Lerner, Gene, 1991, On the syntax of sentences-in-progress. Lang. Soc. 20, 441-458.

Leska, Christel, 1965, Vergleichende Untersuchungen zur Syntax gesprochener und geschriebener deutscher Gegenwartssprache. In: PBB (Ost) 87, 427-464.

Metschkowa-Atanassowa, Sdrawa, 1983, Temporale und konditionale „wenn“-Sätze. Düsseldorf: Schwann.

Selting, Margret et al., 1998, Gesprächsanalytisches Transkriptionssystem. Linguistische Berichte 34, 173, 91-122.

Sweetser, Eve E., 1990, From Etymology to Pragmatics. Metaphorical and Cultural Aspects of Semantic Structure. Cambridge: UP.

Thompson, Sandra, 1985, Grammar and written discourse: initial vs. final purpose clauses in English. Text 5, 55-84

Zifonun, Gisela, et al., 1997, Grammatik der deutschen Sprache. Berlin: de Gruyter, Vol. III. 
Appendix: Regularisation of Transcriptions of Word-Count (example)

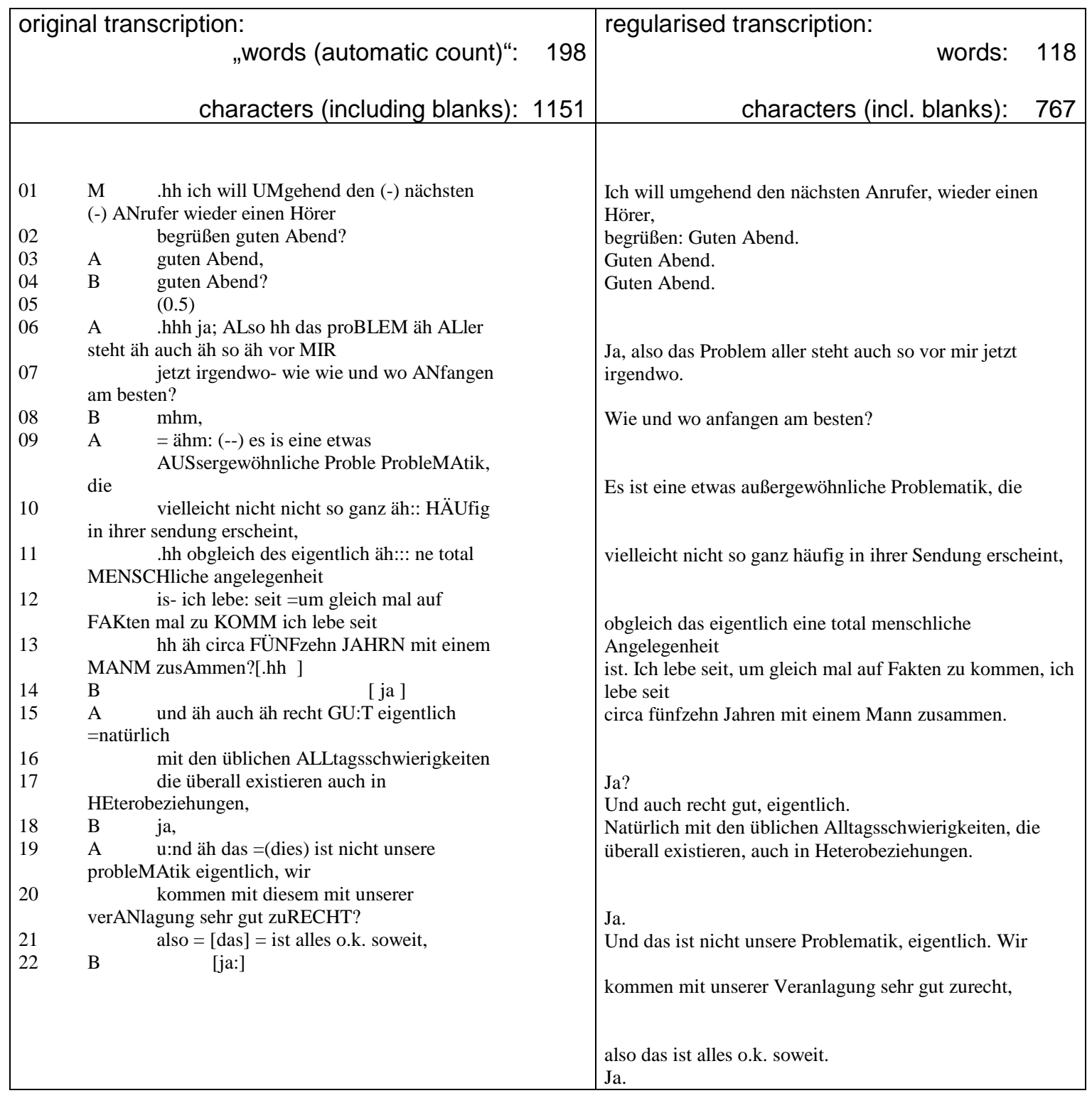




\section{Previously published in this series:}

No.1 Elizabeth Couper-Kuhlen, Coherent Voicing. On Prosody in Conversational Reported Speech (1998)

No.2 Peter Auer, Zwischen Parataxe und Hypotaxe. 'Abhängige Hauptsätze' im gesprochenen und geschriebenen Deutsch (1998)

No.3 Susanne Günthner, Polyphony and the "Layering of Voices" in Reported Dialogues. An Analysis of the Use of Prosodic Devices in Everyday Reported Speech (1998)

No.4 Margret Selting, TCUs and TRPs: The Construction of Units in Conversational Talk (1998)

No.5 Helga Kotthoff, Irony, Quotation, and Other Forms of Staged Intertextuality: Double or Contrastive Perspectivation in Conversation (1998)

No.6 Peter Auer, From Code-Switching via Language Mixing to Fused Lects: Toward a Dynamic Typology of Bilingual Speech (1998)

No.7 Martin Sturm, Mündliche Syntax im schriftlichen Text - ein Vorbild? (1998)

No.8 Elizabeth Couper-Kuhlen, On High Onsets and their Absence in Conversational Interaction

No.9 Margret Selting, Fragments of TCUs as deviant cases of TCU-production in conversational talk

No.10 Barbara Rönfeldt, Paragrammatism reconsidered

No.11 Susanne Günthner, Wenn-Sätze im Vor-Vorfeld: Ihre Formen und Funktionen in der gesprochenen Sprache

No.12 Gabriele Klewitz / Elizabeth Couper-Kuhlen, Quote - Unquote? The role of prosody in the contextualization of reported speech sequences

No.13 Margret Selting: Berlinische Intonationskonturen: 'Der Springton'

No.14 Ines Lange: Die sequentielle Struktur von Anrufbeantworter-Kommunikation. (Nur online unter http://inlist.uni-konstanz.de abrufbar) 